\title{
Applications of Electrochromic Copolymers Based on Tris(4-carbazoyl-9-ylphenyl)amine and Bithiophene Derivatives in Electrochromic Devices
}

\author{
Chung-Wen Kuo ${ }^{1}$, Jui-Cheng Chang ${ }^{2}$, Po-Ying Lee ${ }^{1}$, Tzi-Yi Wu ${ }^{3, * \mathbb{D}}$ and Yu-Chang Huang ${ }^{1}$ \\ 1 Department of Chemical and Materials Engineering, National Kaohsiung University of Science and \\ Technology, Kaohsiung 80778, Taiwan; welly@nkust.edu.tw (C.-W.K.); \\ k40017105@gcloud.csu.edu.tw (P.-Y.L.); ych@nkust.edu.tw (Y.-C.H.) \\ 2 Bachelor Program in Interdisciplinary Studies, National Yunlin University of Science and Technology, \\ Yunlin 64002, Taiwan; d700215@gmail.com \\ 3 Department of Chemical Engineering and Materials Engineering, National Yunlin University of Science and \\ Technology, Yunlin 64002, Taiwan \\ * Correspondence: wuty@gemail.yuntech.edu.tw
}

Received: 6 September 2018; Accepted: 29 September 2018; Published: 3 October 2018

\begin{abstract}
Four copolymers ( $\mathrm{P}(\mathrm{tCz}$ (tris(4-carbazoyl-9-ylphenyl)amine)-co-bTP (2,2'-bithiophene)), $\mathrm{P}(\mathrm{tCz}-\mathrm{co}$-CPDT (4H-cyclopenta[2,1-b:3,4-b']dithiophene)), P(tCz-co-DTC (3,6-di(2-thienyl)carbazole)), and $\mathrm{P}(\mathrm{tCz}-\mathrm{co}-\mathrm{CPDTK}$ (cyclopentadithiophene ketone))) are deposited on indium tin oxide (ITO) surfaces using electrochemical polymerization. Spectroelectrochemical properties of copolymer electrodes reveal that the colors of $\mathrm{P}(\mathrm{tCz}-\mathrm{co}-\mathrm{bTP})$ film are pinkish-orange, light olive green, light grayish blue, and dark blue at $0.0,0.8,1.2$, and $1.6 \mathrm{~V}$, respectively, whereas the color variations of $\mathrm{P}(\mathrm{tCz}-\mathrm{co}-\mathrm{CPDTK})$ film are light yellow, yellow, and blue at $0.0 \mathrm{~V}, 0.8 \mathrm{~V}$, and $1.5 \mathrm{~V}$, respectively. The $\Delta T$ of $\mathrm{P}(\mathrm{tCz}-\mathrm{co}-\mathrm{bTP}), \mathrm{P}(\mathrm{tC} z-\mathrm{co}-\mathrm{CPDT}), \mathrm{P}(\mathrm{tC} z-\mathrm{co}-\mathrm{DTC})$, and $\mathrm{P}(\mathrm{tCz}-\mathrm{co}-\mathrm{CPDTK})$ films are estimated to be $43.0 \%$ at $967 \mathrm{~nm}, 28.7 \%$ at $864 \mathrm{~nm}, 43.6 \%$ at $870 \mathrm{~nm}$, and $24.5 \%$ at $984 \mathrm{~nm}$, respectively. Five electrochromic devices (ECDs) are assembled using the $\mathrm{tCz}$-based homopolymer and copolymers as coloring electrodes, and poly(2,2-dimethyl-3,4-propylenedioxythiophene) (PProDOT-Me 2 ) as the complementary electrode. $\mathrm{P}\left(\mathrm{tCz}-\mathrm{co}\right.$-DTC)/PProDOT-Me $\mathrm{M}_{2} \mathrm{ECD}$ reveals high transmittance change $(45.9 \%$ at $624 \mathrm{~nm}), \mathrm{P}(\mathrm{tCz}-\mathrm{co}-\mathrm{CPDTK}) /$ PProDOT-Me 2 ECD shows high $\eta\left(513.0 \mathrm{~cm}^{2} \mathrm{C}^{-1}\right.$ at $\left.582 \mathrm{~nm}\right)$, and $\mathrm{P}(\mathrm{tCz}-\mathrm{co}-\mathrm{bTP}) /$ PProDOT-Me 2 ECD presents short switching time (less than $0.4 \mathrm{~s}$ ) at $628 \mathrm{~nm}$. Moreover, these ECDs show satisfactory redox stability and open circuit stability.
\end{abstract}

Keywords: copolymer; electrochemical polymerization; spectroelectrochemistry; electrochromic device; redox stability

\section{Introduction}

Electrochromic materials (ECMs) have attracted attention in the scientific communities due to their advantage of low driving voltage and high contrast of transmittance [1]. In around 1960-1970, ECMs have been widely investigated for potential use in automotive rearview mirrors, smart windows, and sunroofs. The most studied electrochromic materials are metal oxides, metal phthalocyanines, metal coordination complexes, viologens, and conjugated polymers [2]. Among these ECMs, conjugated polymers show high coloration efficiency and short response time. The electrochromic behaviors of conjugated polymers can be tuned by proper incorporations of specific substituents in polymer backbones [3].

The commonly used conjugated polymers of ECMs contain polythiophene [4,5], polycarbazole [6,7], polytriphenylamine [8,9], polyaniline [10], polyindole [11,12], and poly $(3,4-$ 
ethylenedioxythiophene) (PEDOT) [13]. Polycarbazoles have been extensively studied for various optical and electrochemical devices due to their superior electroactive properties. Polycarbazoles can be functionalized at the 3,6-, 2,7-, and 9-positions of carbazole groups [14,15]. Polythiophene can be easily modified to offer a wide variety of useful optical and electrochemical properties such as tunable band gap, conductivity, and oxidation and reduction activity [16,17]. Jia et al. [18] reported the electrochromic properties of poly(carbazoyltriphenylamine) (poly(CBZ-TPA)) and poly(carbazoyltriphenylaminethiophene) (poly(CBZ-TPA-Th)) films. Poly(CBZ-TPA) film displayed camel gray, light gray, and army green at $-0.5,0$, and $1.6 \mathrm{~V}$, respectively, whereas poly(CBZ-TPA-Th) film exhibited maize-yellow, milk white, and dark green at -0.5 , 0 , and $1.4 \mathrm{~V}$, respectively. Yigit et al. [19] reported the spectroelectrochemical characterization of azobenzene- and coumarin-containing polymers (poly[9-(2-4-(phenyldiazenyl) phenoxy) ethyl-3,6-di(thiophen-2-yl)-9H-car-bazole] (PTCbzAz), poly[3,6-bis(2,3-dihydrothieno[3,4-b][1, 4]di-oxin-5-yl)-9-(2-(4-(phenyldiazenyl)phenoxy) ethyl)-9H-carbazole] (PECbzAz), poly[4-(2-(3,6-di(thiophen-2-yl)-9H-carba-zol-9-yl) ethoxy)-2H-chromen-2-one] (PTCbzCo) and poly[3,6-bis (2,3-dihydrothieno[3,4-b][1,4]dioxin-5-yl)-9H-(carbazol-9-yl)ethoxy-2H-chromen-2-one] $(\mathrm{PECbzCo}))$. The spectroelectrochemical studies showed that the incorporations of azobenzene and coumarin units in polymer backbone gave rise to multicolored electrochromisms. Moreover, PProDOT-Me $\mathrm{Me}_{2}$ is one of the promising polythiophene derivatives. PProDOT-Me $\mathrm{M}_{2}$ has been employed as the cathodically coloring material of ECDs due to PProDOT-Me $\mathrm{M}_{2}$ film being transparent in the oxidized state and the resulting deep color in the reduced state [20]. Furthermore, copolymerization is a promising way to tune the electrochromic characteristics of polymer films. Copolymerization of various monomers containing specific functional groups can bring about interesting electrochromic behaviors. For this matter, four carbazole- and bithiophene-containing copolymers ( $\mathrm{P}(\mathrm{tCz}-\mathrm{co}-\mathrm{bTP}$ (2,2'-bithiophene)), P(tCz-co-CPDT), P(tCz-co-DTC (3,6-di(2-thienyl)carbazole)), and P(tCz-co-CPDTK (cyclopentadithiophene ketone))) are copolymerized electrochemically to study their promising applications as ECMs. tCz contains three carbazole units linked by a triphenylamine core. The presence of three oxidizable carbazole and one oxidizable triphenylamine groups in $\mathrm{tCz}$ unit facilitates the formations of polaron and bipolaron in the oxidized states of $\mathrm{tCz}$-based polymer films. All of bTP, CPDT, DTC, and CPDTK units comprise two thiophene rings linked by specific groups. The two thiophene rings of bTP and DTC units are linked by a single bond and a carbazole group, respectively. CPDT comprises two thiophene rings linked by a single bond and a methylene bridge at the 2- and 3-positions of thiophene rings. CPDTK contains two thiophene rings linked by a carbonyl group and a single bond at the 2- and 3-positions of thiophene rings. The electron-withdrawing carbonyl group in CPDTK unit can diminish the LUMO level and band gap of polymers, which is useful in electrochromic applications. Moreover, five ECDs comprised of PtCz, P(tCz-co-bTP), P(tCz-co-CPDT), $\mathrm{P}\left(\mathrm{tCz}-\mathrm{co}\right.$-DTC), or $\mathrm{P}(\mathrm{tCz}-\mathrm{co}-\mathrm{CPDTK})$ as anodically coloring layer, and PProDOT- $\mathrm{Me}_{2}$ as cathodically coloring layer were constructed and their spectroelectrochemical behaviors, transmittance variations of electrochromic switching, optical memory, and redox stability were also investigated.

\section{Experimental}

\subsection{Materials}

2,2'-bithiophene (bTP), CPDT, and CPDTK were purchased from Luminescence Technology Corp. (Taipei, Taiwan). ProDOT-Me 2 , DTC, and $\mathrm{tCz}$ were synthesized according to previously published procedures [21-23].

\subsection{Electrosynthesis of $P t C z, P(t C z-c o-b T P), P(t C z-c o-C P D T), P(t C z-c o-D T C), P(t C z-c o-C P D T K)$, and PProDOT-Me $\mathrm{N}_{2}$ Films}

The electrosynthesis of PtCz, P(tCz-co-bTP $), \quad \mathrm{P}(\mathrm{tCz}-\mathrm{co}-\mathrm{CPDT}), \quad \mathrm{P}(\mathrm{tCz}-\mathrm{co}-\mathrm{DTC})$, and $\mathrm{P}\left(\mathrm{tCz}-\mathrm{co}\right.$-CPDTK) films was carried out in a $0.2 \mathrm{M} \mathrm{LiClO}_{4} /$ acetonitrile (ACN)/dichloromethane 
(DCM) solution, and the feed molar ratio of monomers are presented in Table 1. The PtCz, $\mathrm{P}(\mathrm{tCz}-\mathrm{co}-\mathrm{bTP}), \mathrm{P}(\mathrm{tCz}-\mathrm{co}-\mathrm{CPDT}), \mathrm{P}(\mathrm{tCz}-\mathrm{co}-\mathrm{DTC})$, and $\mathrm{P}(\mathrm{tCz}-\mathrm{co}-\mathrm{CPDTK})$ films were prepared potentiodynamically by scanning the potential between $0.0 \mathrm{~V}$ and $1.8 \mathrm{~V}$ (vs. $\mathrm{Ag} / \mathrm{AgCl}$ in $3 \mathrm{M} \mathrm{KCl}$ solution) for 3 cycles. The PProDOT-Me $\mathrm{M}_{2}$ film was prepared using $2 \mathrm{mM}$ ProDOT-Me $\mathrm{Me}_{2}$ in a $0.2 \mathrm{M}$ $\mathrm{LiClO}_{4}$-containing ACN solution. PProDOT-Me 2 film was deposited potentiostatically at $1.7 \mathrm{~V}$ (vs. $\mathrm{Ag} / \mathrm{AgCl}$ in $3 \mathrm{M} \mathrm{KCl}$ solution).

Table 1. Feed species of anodic polymer electrodes.

\begin{tabular}{|c|c|c|}
\hline Anodic Polymer Electrodes & Feed Species of Anodic Polymers & Feed Molar Ratio of Anodic Polymers \\
\hline $\mathrm{PtCz}$ & $2 \mathrm{mM} \mathrm{tCz}$ & Neat $\mathrm{tCz}$ \\
\hline $\mathrm{P}(\mathrm{tC} \mathrm{C}-\mathrm{co}-\mathrm{bTP})$ & $2 \mathrm{mM} \mathrm{tCz}+2 \mathrm{mM} b T P$ & $\mathrm{tCz}: \mathrm{bTP}=1: 1$ \\
\hline $\mathrm{P}(\mathrm{tC} \mathrm{C}-\mathrm{co}-\mathrm{CPDT})$ & $2 \mathrm{mM} \mathrm{tCz}+2 \mathrm{mM} C P D T$ & $\mathrm{tCz}: \mathrm{CPDT}=1: 1$ \\
\hline $\mathrm{P}(\mathrm{tCz}-\mathrm{co}-\mathrm{DTC})$ & $2 \mathrm{mM} \mathrm{tCz}+2 \mathrm{mM}$ DTC & tCz:DTC = 1:1 \\
\hline $\mathrm{P}(\mathrm{tCz}-\mathrm{co}-\mathrm{CPDTK})$ & $2 \mathrm{mM} \mathrm{tCz}+2 \mathrm{mM}$ CPDTK & $\mathrm{tCZ}: \mathrm{CPDTK}=1: 1$ \\
\hline
\end{tabular}

\subsection{Electrochemical and Spectroelectrochemical Characterizations}

Electrochemical characterizations of $\mathrm{PtC}, \mathrm{P}(\mathrm{t} C \mathrm{z}-\mathrm{co}-\mathrm{bTP}), \mathrm{P}(\mathrm{tCz}-\mathrm{co}-\mathrm{CPDT}), \mathrm{P}(\mathrm{t} C \mathrm{z}-\mathrm{co}-\mathrm{DTC})$, $\mathrm{P}(\mathrm{tCz}-\mathrm{co}-\mathrm{CPDTK})$ films and their corresponding ECDs were performed using a CHI627D electrochemical analyzer (CH Instruments, Austin, TX, USA). The active areas of $\mathrm{PtCz}, \mathrm{P}(\mathrm{tCz}-\mathrm{co}-\mathrm{bTP})$, $\mathrm{P}(\mathrm{tCz}-\mathrm{co}-\mathrm{CPDT}), \mathrm{P}(\mathrm{tCz}-\mathrm{co}-\mathrm{DTC}), \mathrm{P}(\mathrm{tCz}-\mathrm{co}-\mathrm{CPDTK})$, and PProDOT-Me ${ }_{2}$ films on ITO coated glass plate were $1.5 \mathrm{~cm}^{2}$. The characterizations of polymer films in ACN/DCM solution were carried out using $\mathrm{Ag} / \mathrm{AgCl}$ and platinum wire as the reference and counter electrodes, respectively. Spectroelectrochemical characterizations were performed using an Agilent Cary $60 \mathrm{UV}$ (Ultraviolet)-Visible spectrophotometer (Varian Inc., Walnut Creek, CA, USA) and a CHI627D electrochemical analyzer.

\subsection{Construction of Electrochromic Devices}

The electrolyte of ECD was prepared using poly(methyl methacrylate) (PMMA), propylene carbonate (PC), and $\mathrm{LiClO}_{4}$, the weight ratio of PMMA:PC: $\mathrm{LiClO}_{4}$ is 33:53:14. Electrochromic devices were fabricated using PtCz, P(tCz-co-bTP), P(tCz-co-CPDT), P(tCz-co-DTC), or P(tCz-co-CPDTK) as the anodic coloring layer and PProDOT-Me $\mathrm{M}_{2}$ as the cathodic coloring layer. Both anodic coloring and cathodic coloring materials were electrodeposited on ITO glasses, respectively. The ECDs were constructed by arranging the anodic and cathodic coloring layers to face each other, and they were separated by the PMMA/PC/ $\mathrm{LiClO}_{4}$ electrolyte.

\section{Results and Discussion}

\subsection{Electrochemical Polymerization}

Figure 1 showed the electrooxidation of $2 \mathrm{mM} \mathrm{tCz}, 2 \mathrm{mM}$ bTP, $2 \mathrm{mM}$ CPDT, $2 \mathrm{mM}$ DTC, and $2 \mathrm{mM}$ CPDTK in $0.2 \mathrm{M} \mathrm{LiClO}_{4} / \mathrm{ACN} / \mathrm{DCM}$ solution. The onset potential of oxidation for tCz, bTP, CPDT, DTC, and CPDTK were $0.78,0.83,0.89,0.79$, and $0.93 \mathrm{~V}$, respectively. CPDTK showed higher onset potential of oxidation than those of bTP and CPDT, indicating the incorporation of electron withdrawing ketone group in CPDTK increasing the onset potential of oxidation significantly. The discrepancies between $\mathrm{tC} z$ vs. bTP, $\mathrm{tC} z$ vs. CPDT, $\mathrm{tCz}$ vs. DTC, and $\mathrm{tCz}$ vs. CPDTK were less than $0.15 \mathrm{~V}$, implying that the copolymerizations of $\mathrm{tCz}$ vs. bTP, tCz vs. CPDT, tCz vs. DTC, and tCz vs. CPDTK are workable [24]. 


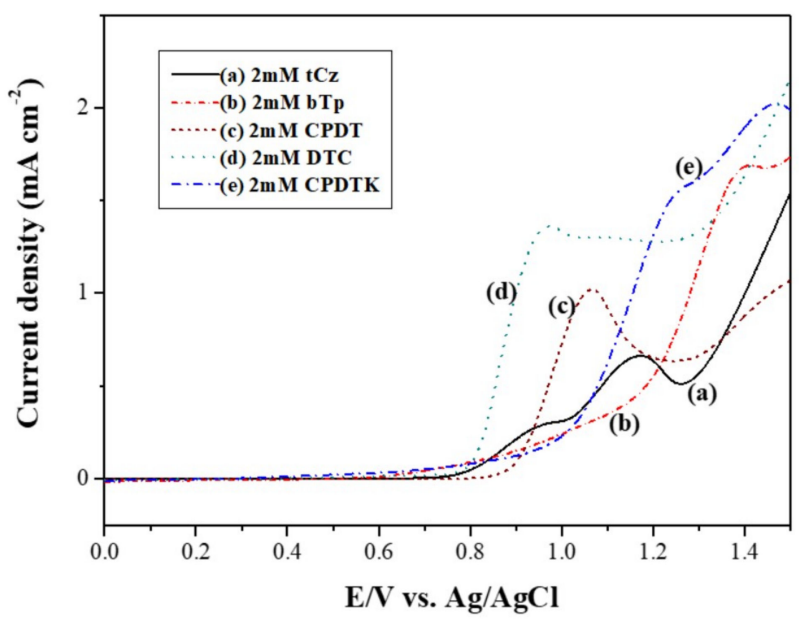

Figure 1. Electrooxidation of (a) $2 \mathrm{mM} \mathrm{tCz}$; (b) $2 \mathrm{mM} \mathrm{bTP}$; (c) $2 \mathrm{mM} \mathrm{CPDT}$; (d) $2 \mathrm{mM} \mathrm{DTC}$; and (e) $2 \mathrm{mM}$ CPDTK at a scan rate of $100 \mathrm{mV} \mathrm{s}^{-1}$.

Figure 2 shows the electrochemical synthesis of copolymer films in a solution. The redox peak current densities increased with the increasing number of cycles, indicating the formation of polymer films on ITO substrates [25]. The oxidation peaks of $\mathrm{P}(\mathrm{tCz}-\mathrm{co}-\mathrm{bTP}), \mathrm{P}(\mathrm{tCz}-\mathrm{co}-\mathrm{CPDT}), \mathrm{P}(\mathrm{tCz}-\mathrm{co}-\mathrm{DTC})$, and $\mathrm{P}(\mathrm{tCz}-\mathrm{co}$-CPDTK) located at around 1.10, 1.35, 1.45, and $1.10 \mathrm{~V}$, respectively, and the reduction peaks of $\mathrm{P}(\mathrm{tCz}-\mathrm{co}-\mathrm{bTP}), \mathrm{P}(\mathrm{tCz}-\mathrm{co}-\mathrm{CPDT}), \mathrm{P}(\mathrm{tCz}-\mathrm{co}-\mathrm{DTC})$, and $\mathrm{P}(\mathrm{tCz}-\mathrm{co}-\mathrm{CPDTK})$ located at around 0.65, $0.73,0.70$, and $0.60 \mathrm{~V}$, respectively. The polymerization schemes of $\mathrm{P}(\mathrm{tCz}-\mathrm{co}-\mathrm{bTP}), \mathrm{P}(\mathrm{tCz}-\mathrm{co}-\mathrm{CPDT})$, $\mathrm{P}(\mathrm{tCz}-\mathrm{co}-\mathrm{DTC})$, and $\mathrm{P}(\mathrm{tCz}-\mathrm{co}-\mathrm{CPDTK})$ are displayed in Figure 3.
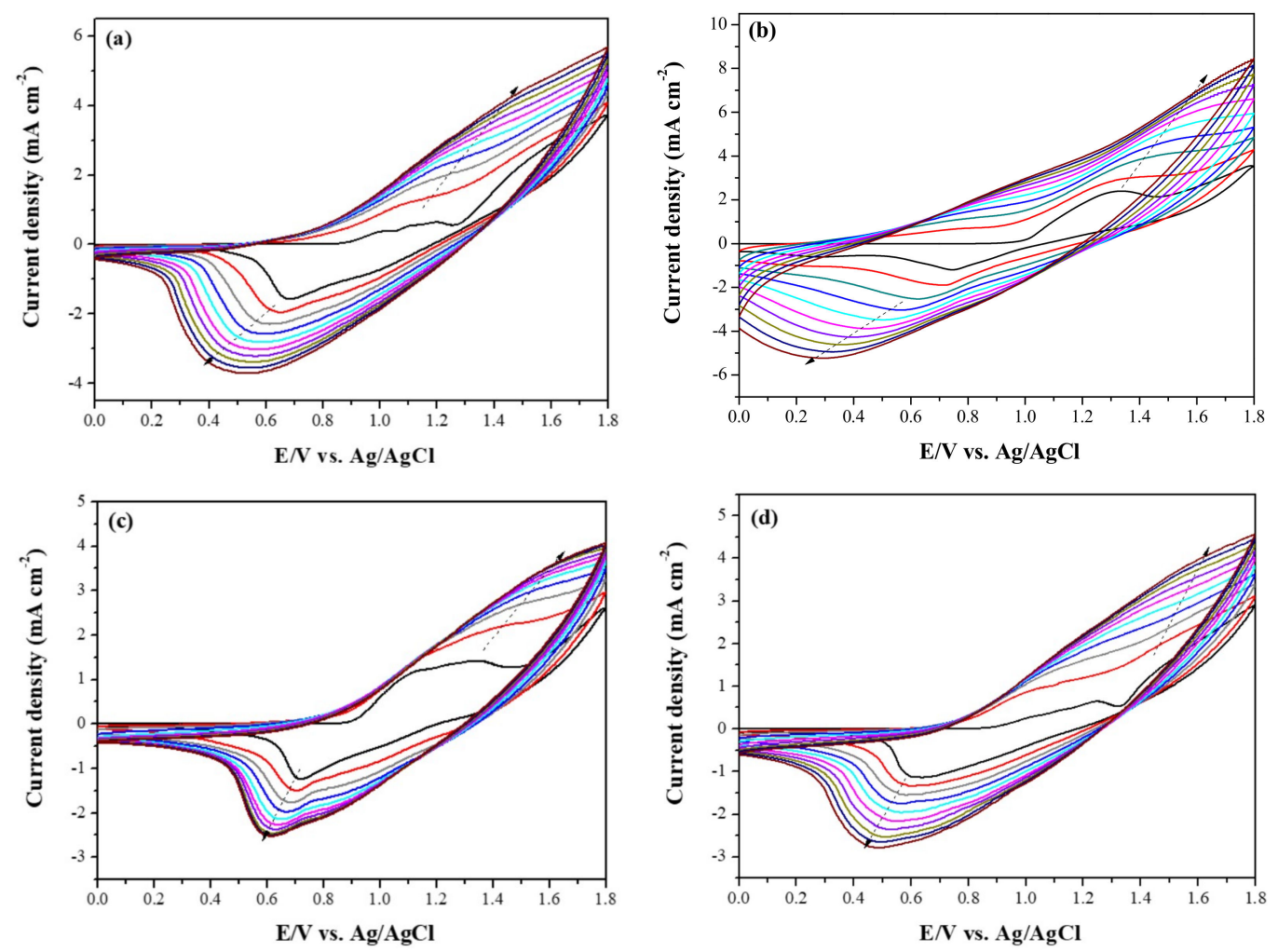

Figure 2. Electrochemical synthesis of (a) $\mathrm{P}(\mathrm{tCz}-\mathrm{co}-\mathrm{bTP})$; (b) $\mathrm{P}(\mathrm{tCz}-\mathrm{co}-\mathrm{CPDT})$; (c) $\mathrm{P}(\mathrm{tCz}-\mathrm{co}-\mathrm{DTC})$; and (d) $\mathrm{P}\left(\mathrm{tCz}-\mathrm{co}\right.$-CPDTK) in $0.2 \mathrm{M} \mathrm{LiClO}_{4} / \mathrm{ACN} / \mathrm{DCM}$ solution. 

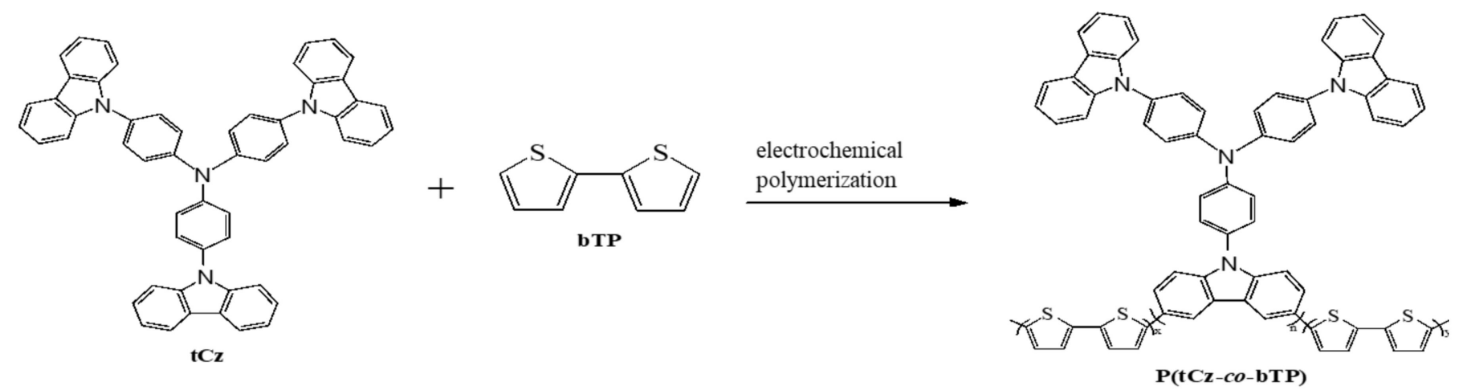

(a)
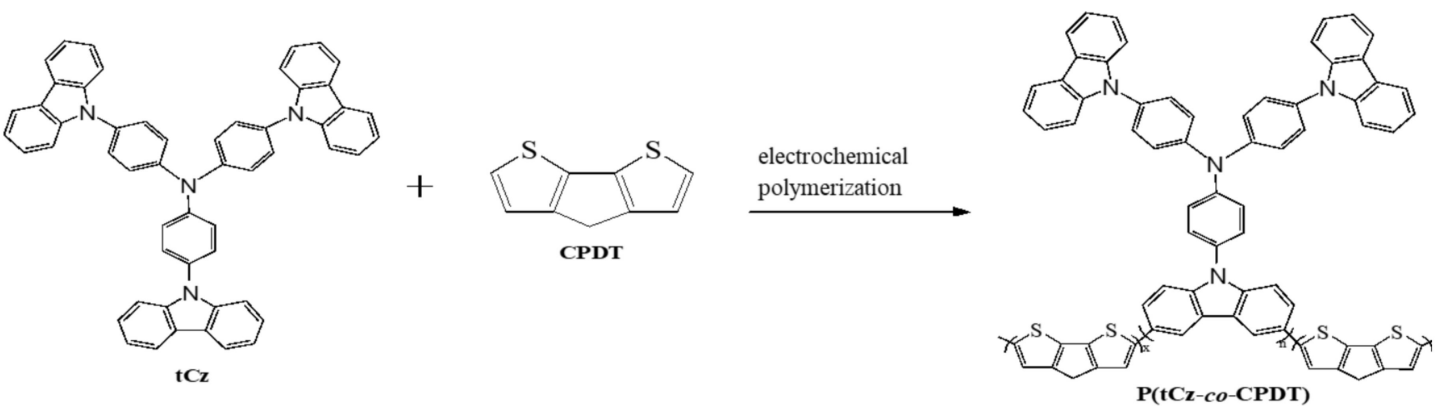

(b)
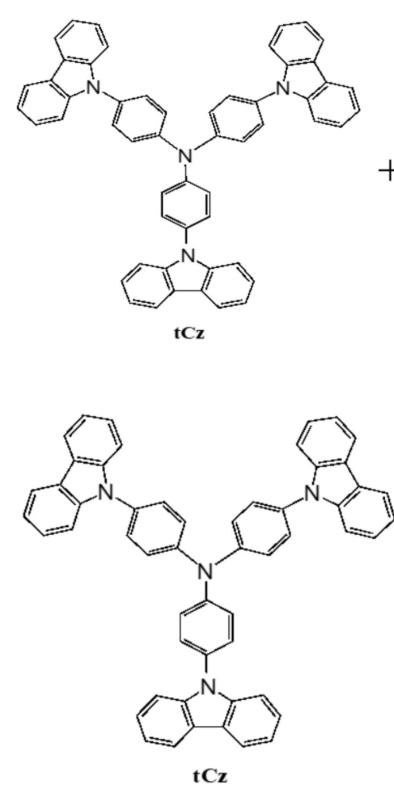
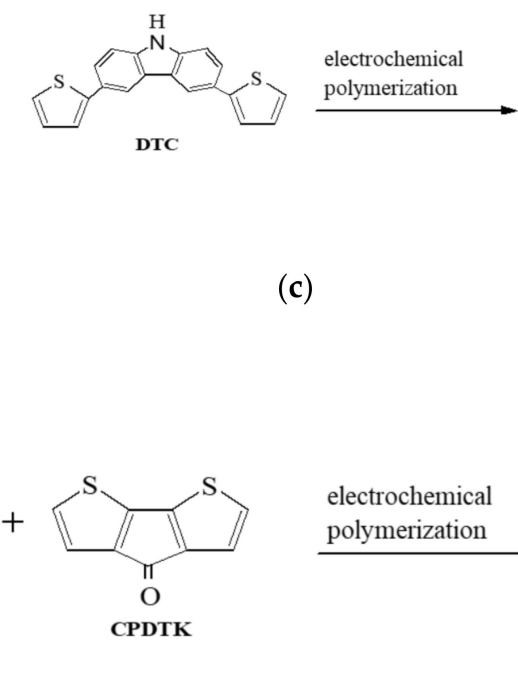

(c)

(d) electrochemical polymerization
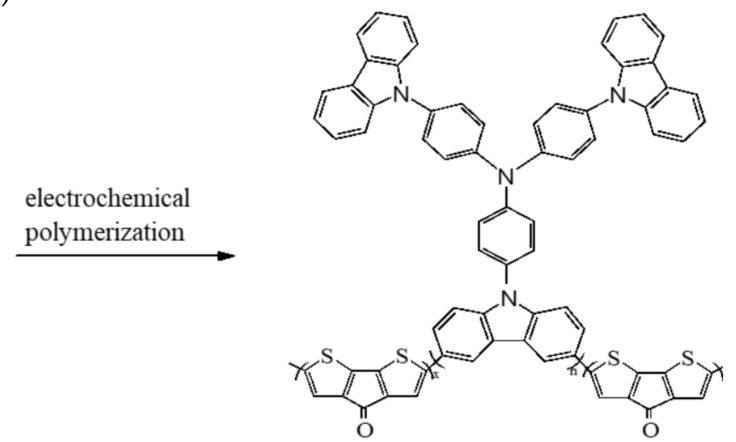

P(tCz-co-CPDTK)

Figure 3. The polymerization schemes of (a) $\mathrm{P}(\mathrm{tCz}-\mathrm{co}-\mathrm{bTP})$; (b) $\mathrm{P}(\mathrm{tCz}-\mathrm{co}-\mathrm{CPDT})$; (c) $\mathrm{P}(\mathrm{tCz}-\mathrm{co}-\mathrm{DTC})$; and (d) P(tCz-co-CPDTK).

\subsection{Electrochemical Behavior of $P(t C z-c o-D T C)$ Film}

The $\mathrm{P}(\mathrm{tCz}-\mathrm{co}-\mathrm{DTC})$ film was synthesized using the electropolymerization of $\mathrm{tCz}$ and DTC monomers were scanned at different scan rate in $0.2 \mathrm{M} \mathrm{LiClO}_{4} / \mathrm{ACN} / \mathrm{DCM}$ solution. As shown in Figure 4, cyclic voltammogram (CV) curves of $\mathrm{P}(\mathrm{tCz}-\mathrm{co}$-DTC) film showed well-defined redox peaks and the peak current densities increased linearly with the increasing scan rates (inset in Figure 4), demonstrating that the redox process is electroactively non-diffusional limited and $\mathrm{P}(\mathrm{tCz}-\mathrm{co}$-DTC $)$ film has adhered well to the ITO electrode [26]. 


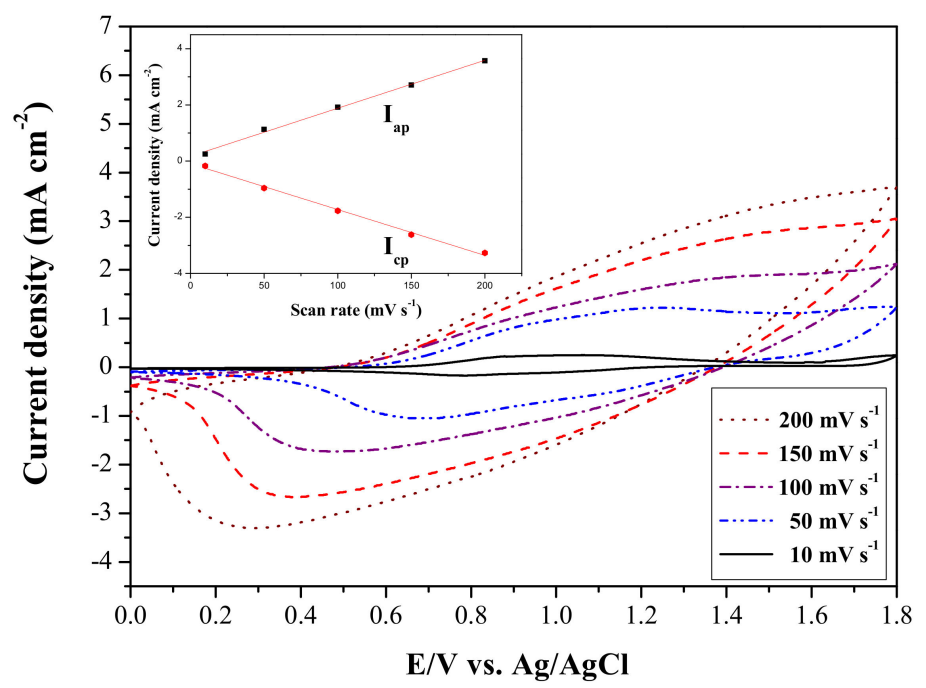

Figure 4. $\mathrm{CV}$ curves of the $\mathrm{P}(\mathrm{tCz}-\mathrm{co}-\mathrm{DTC})$ film at different scan rates. Inset: Scan rate dependence of the peak current densities of $\mathrm{P}(\mathrm{tCz}-\mathrm{co}-\mathrm{DTC})$ film.

\subsection{Spectroelectrochemical Studies of Polymer Films}

$\mathrm{P}(\mathrm{tCz}-\mathrm{co}-\mathrm{bTP}), \mathrm{P}(\mathrm{tCz}-\mathrm{co}-\mathrm{CPDT}), \mathrm{P}(\mathrm{tCz}-\mathrm{co}-\mathrm{DTC})$, and $\mathrm{P}(\mathrm{tC} z-c o-C P D T K)$ films were coated on ITO substrate and the spectral variations at various voltages were monitored using a UV-Vis spectrophotometer. As shown in Figure $5 \mathrm{a}, \mathrm{P}(\mathrm{tCz}-\mathrm{co}-\mathrm{bTP})$ film has an absorption peak at $450 \mathrm{~nm}$ in the neutral state at $0.0 \mathrm{~V}$, which can be referred to the $\pi-\pi^{*}$ transition of $\mathrm{P}(\mathrm{tCz}-\mathrm{co}-\mathrm{bTP})$, and $\mathrm{P}(\mathrm{tCz}-\mathrm{co}-\mathrm{bTP})$ film being light orange in the neutral state.
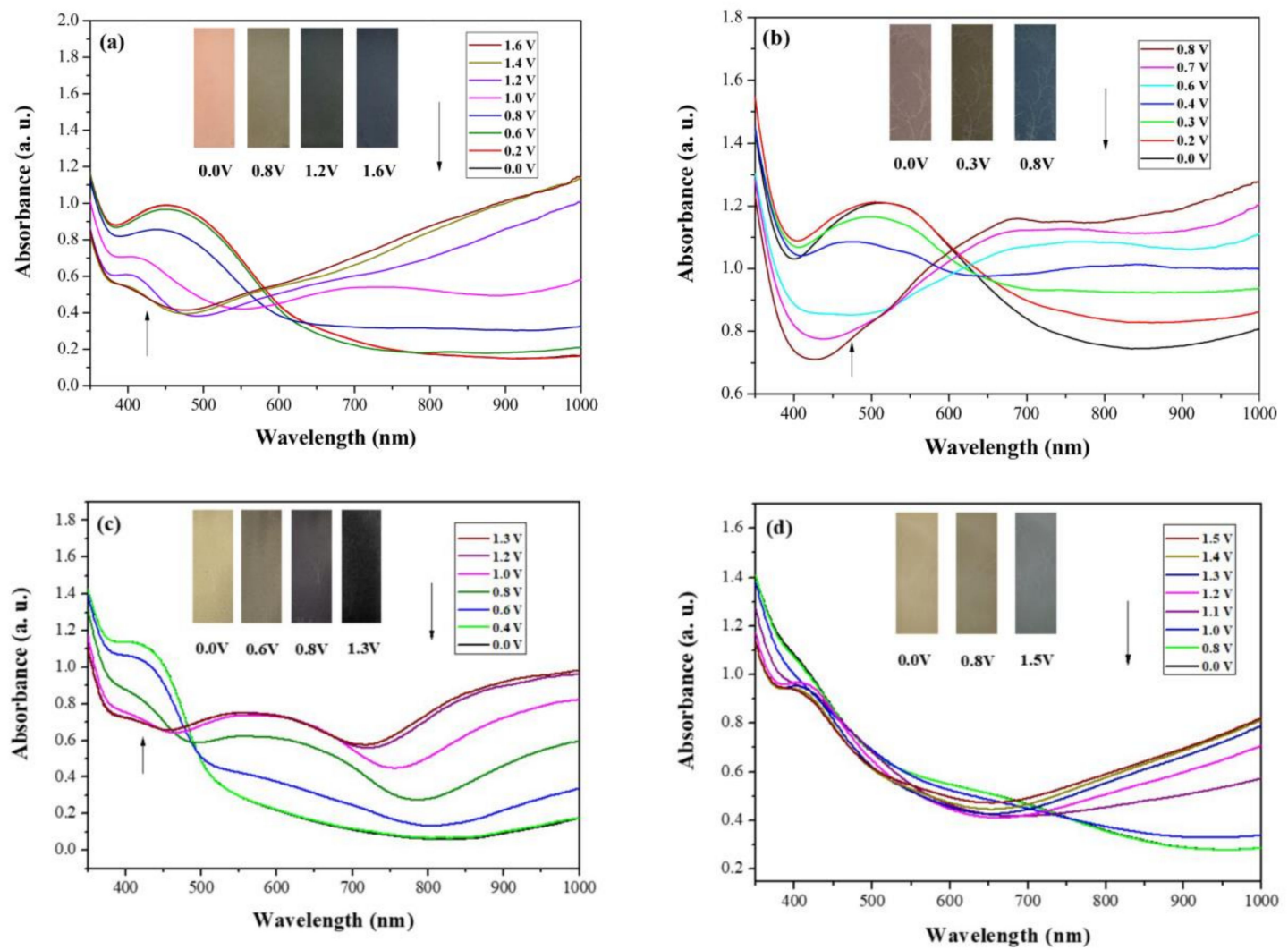

Figure 5. UV-Visible spectra of (a) $\mathrm{P}(\mathrm{tCZ}-\mathrm{co}-\mathrm{bTP})$; (b) $\mathrm{P}(\mathrm{tCz}-\mathrm{co}-\mathrm{CPDT})$; (c) $\mathrm{P}(\mathrm{tCz}-\mathrm{co}-\mathrm{DTC})$; and (d) $\mathrm{P}(\mathrm{tCz}-\mathrm{co}-\mathrm{CPDTK})$ electrodes in $0.2 \mathrm{M} \mathrm{LiClO}_{4} / \mathrm{ACN} / \mathrm{DCM}$ solution. 
Table 2. Colorimetric values of (a) $\mathrm{P}(\mathrm{tCz}-\mathrm{co}-\mathrm{bTP})$; (b) $\mathrm{P}(\mathrm{tCz}-\mathrm{co}-\mathrm{CPDT})$; (c) P(tCz-co-DTC); and (d) $\mathrm{P}(\mathrm{tCz}-\mathrm{co}-\mathrm{CPDTK})$ at various potentials.

(a)

\begin{tabular}{|c|c|c|c|c|c|c|}
\hline Potentials (V) & $L^{*}$ & $a^{*}$ & $\mathbf{b}^{*}$ & $x$ & $y$ & Diagram \\
\hline 0.0 & 59.71 & 25.70 & 35.21 & 0.5478 & 0.3972 & \multirow{7}{*}{ 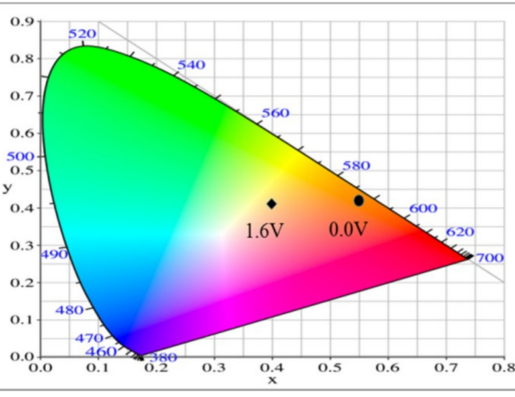 } \\
\hline 0.6 & 61.13 & 26.79 & 35.94 & 0.5491 & 0.3962 & \\
\hline 0.8 & 64.73 & 17.19 & 32.72 & 0.5227 & 0.4117 & \\
\hline 1.0 & 66.51 & -5.10 & 13.39 & 0.4541 & 0.4317 & \\
\hline 1.2 & 65.02 & -9.35 & -3.89 & 0.4221 & 0.4168 & \\
\hline 1.4 & 62.61 & -8.10 & -9.70 & 0.4154 & 0.4066 & \\
\hline 1.6 & 61.80 & -8.19 & -9.45 & 0.4152 & 0.4071 & \\
\hline
\end{tabular}

(b)

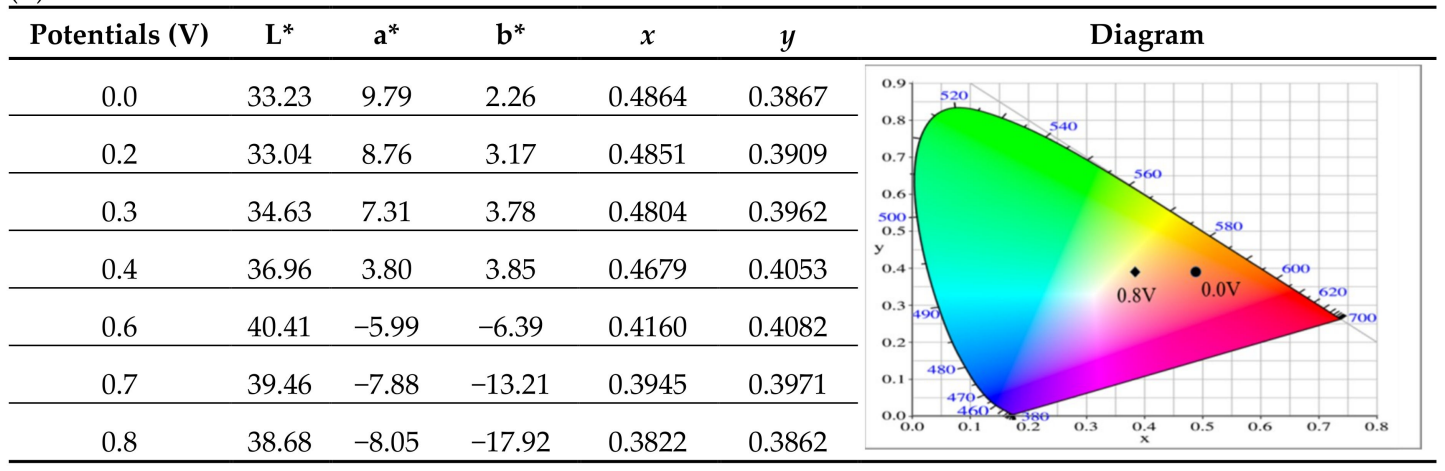

(c)

\begin{tabular}{|c|c|c|c|c|c|c|}
\hline Potentials (V) & $L^{*}$ & $a^{*}$ & $\mathbf{b}^{*}$ & $x$ & $y$ & Diagram \\
\hline 0.0 & 78.67 & 10.33 & 56.32 & 0.5184 & 0.4378 & ${ }^{0.9}$ ] \\
\hline 0.4 & 78.54 & 10.66 & 55.83 & 0.5177 & 0.4380 & 0.7 . \\
\hline 0.6 & 69.27 & 5.59 & 36.01 & 0.4992 & 0.4343 & $\begin{array}{c}0.6 \\
\text { soot }\end{array}$ \\
\hline 0.8 & 56.67 & 0.98 & 5.35 & 0.4580 & 0.4130 & $\begin{array}{l}y_{0.4} \\
.\end{array}$ \\
\hline 1.0 & 50.67 & 1.78 & -5.50 & 0.4426 & 0.3955 & \\
\hline 1.2 & 50.04 & 2.84 & -5.54 & 0.4452 & 0.3934 & 0.1 . \\
\hline 1.3 & 50.17 & 2.77 & -5.43 & 0.4452 & 0.3937 & 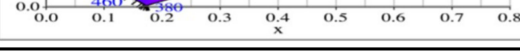 \\
\hline
\end{tabular}

(d)

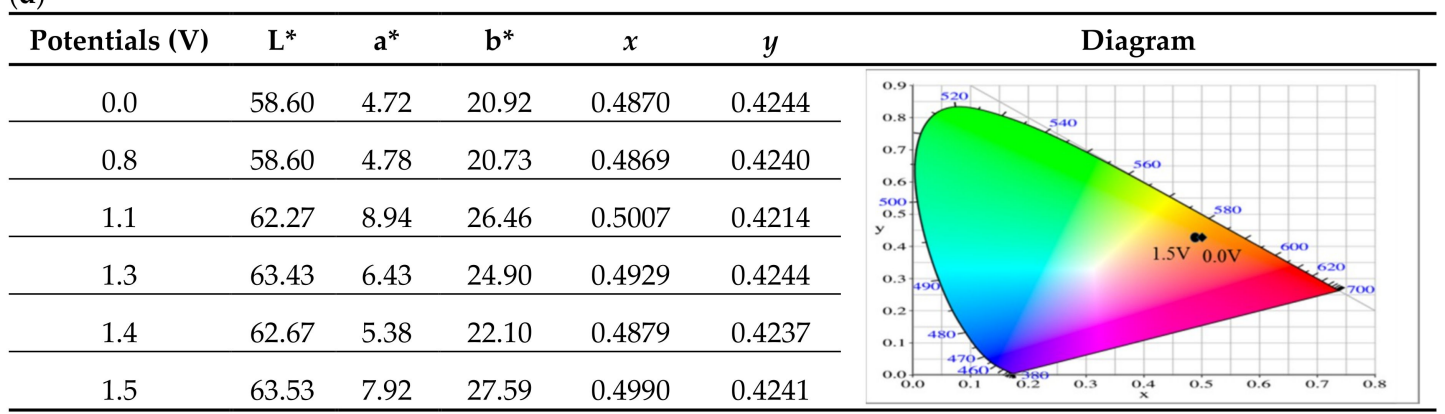

Upon increasing the voltage in the positive direction, the new absorption band at $967 \mathrm{~nm}$ emerged gradually, which are assigned to the formation of polaron and bipolaron absorption bands [27]. The colors of $\mathrm{P}(\mathrm{tCz}-\mathrm{co}-\mathrm{bTP})$ film were dark yellow, light blue and dark blue at $0.8,1.2$, and $1.6 \mathrm{~V}$, respectively. In similar condition, $\mathrm{P}(\mathrm{tCz}-\mathrm{co}-\mathrm{CPDT}), \mathrm{P}(\mathrm{tCz}-\mathrm{co}-\mathrm{DTC})$, and $\mathrm{P}(\mathrm{tCz}-\mathrm{co}-\mathrm{CPDTK})$ films showed the maximum absorption at 500,420, and $410 \mathrm{~nm}$ in the neutral state, respectively. This may be 
attributed to the effective conjugation of the polymer chains [28]. The colors of $\mathrm{P}(\mathrm{tCz}-\mathrm{co}-\mathrm{CPDT})$ film were light purple at $0.0 \mathrm{~V}$, green at $0.3 \mathrm{~V}$, and dark blue at $0.8 \mathrm{~V}$, whereas the color variations of $\mathrm{P}(\mathrm{tCz}$-co-DTC) film were light yellow at $0.0 \mathrm{~V}$, yellow at $0.6 \mathrm{~V}$, blue at $0.8 \mathrm{~V}$, and black at $1.3 \mathrm{~V}$, the color variations of $\mathrm{P}(\mathrm{tCz}$-co-CPDTK) film were light yellow at $0.0 \mathrm{~V}$, yellow at $0.8 \mathrm{~V}$, and blue at $1.5 \mathrm{~V}$. Table 2 shows the colorimetric values of $\mathrm{P}(\mathrm{tCz}-\mathrm{co}-\mathrm{bTP}), \mathrm{P}(\mathrm{tCz}-\mathrm{co}-\mathrm{CPDT}), \mathrm{P}(\mathrm{tC} z-\mathrm{co}-\mathrm{DTC})$, and $\mathrm{P}(\mathrm{tCz}-\mathrm{co}-\mathrm{CPDTK})$ at various applied potentials.

\subsection{Electrochemical Switching of Polymer Films}

Figure 6 shows the electrochromic switching properties of $\mathrm{PtC}, \mathrm{P}(\mathrm{tCz}-\mathrm{co}-\mathrm{bTP}), \mathrm{P}(\mathrm{tC}-\mathrm{co}-\mathrm{CPDT})$, $\mathrm{P}(\mathrm{tCz}-\mathrm{co}-\mathrm{DTC})$, and $\mathrm{P}(\mathrm{tCZ}-\mathrm{co}-\mathrm{CPDTK})$ films in a $0.2 \mathrm{M} \mathrm{LiClO}_{4} / \mathrm{ACN} / \mathrm{DCM}$ solution, and the optical contrast $(\Delta T \%)$ and $\Delta \mathrm{OD}$ of polymer films were listed in Table 3 . The polymer films were switched by potentials between 0.0 and $1.5 \mathrm{~V}$ with a time interval of $10 \mathrm{~s}$. The $\Delta T$ of $\mathrm{PtCz}, \mathrm{P}(\mathrm{tCz}-\mathrm{co}-\mathrm{bTP})$, $\mathrm{P}(\mathrm{tCz}-\mathrm{co}-\mathrm{CPDT}), \mathrm{P}(\mathrm{tCz}-\mathrm{co}-\mathrm{DTC})$, and $\mathrm{P}(\mathrm{tCz}-\mathrm{co}-\mathrm{CPDTK})$ films were estimated to be $30.5 \%$ at $760 \mathrm{~nm}$, $43.0 \%$ at $967 \mathrm{~nm}, 28.7 \%$ at $864 \mathrm{~nm}, 43.6 \%$ at $870 \mathrm{~nm}$, and $24.5 \%$ at $984 \mathrm{~nm}$, respectively. P(tCz-co-bTP) and $\mathrm{P}(\mathrm{tCz}-\mathrm{co}-\mathrm{DTC})$ films showed a higher $\Delta T$ than those of PtCz, P(tCz-co-CPDT), and P(tCz-co-CPDTK) films, implying the incorporation of bTP and DTC units in the copolymer backbone enhances $\Delta T$ significantly. The response time required to reach $90 \%$ of entire transmittance change were determined to be $3.5-6.5 \mathrm{~s}$ for these polymer films.

The $\eta$ can be determined using the formula [29]:

$$
\eta=\frac{\Delta O D}{Q_{d}}
$$

where $Q_{\mathrm{d}}$ refers to the amount of injected/ejected charge per unit active area. The $\eta$ values of $\mathrm{PtC} z, \mathrm{P}(\mathrm{tCz}-\mathrm{co}-\mathrm{bTP}), \mathrm{P}(\mathrm{tCz}-\mathrm{co}-\mathrm{CPDT}), \mathrm{P}(\mathrm{tCz}-\mathrm{co}-\mathrm{DTC})$, and $\mathrm{P}(\mathrm{tC} z-\mathrm{co}-\mathrm{CPDTK})$ films are calculated to be $42.6 \mathrm{~cm}^{2} \mathrm{C}^{-1}$ at $760 \mathrm{~nm}, 67.6 \mathrm{~cm}^{2} \mathrm{C}^{-1}$ at $967 \mathrm{~nm}, 76.7 \mathrm{~cm}^{2} \mathrm{C}^{-1}$ at $864 \mathrm{~nm}, 78.3 \mathrm{~cm}^{2} \mathrm{C}^{-1}$ at $870 \mathrm{~nm}$, and $62.5 \mathrm{~cm}^{2} \mathrm{C}^{-1}$ at $984 \mathrm{~nm}$, respectively. Copolymer films show higher $\eta$ values than that of $\mathrm{PtCz}$ film in a solution.

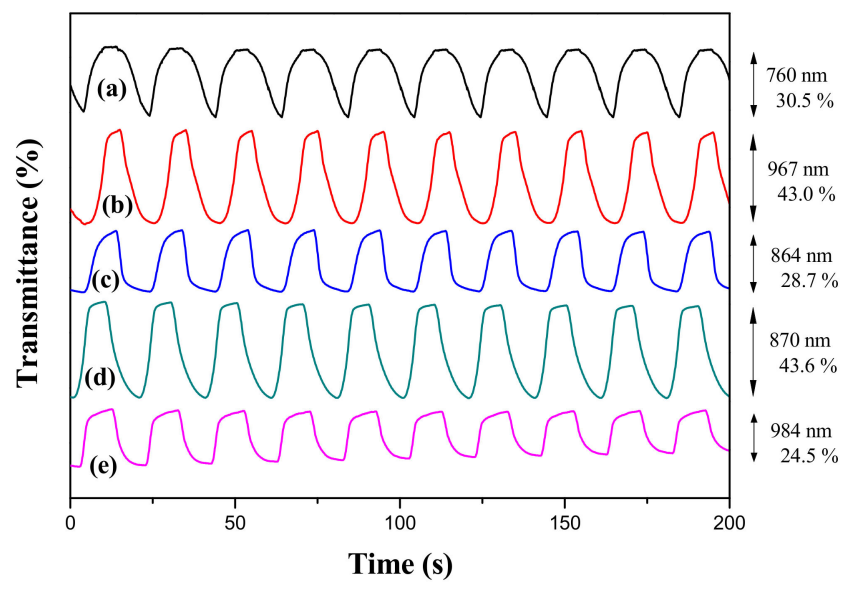

Figure 6. Transmittance-time profiles of (a) PtCz; (b) $\mathrm{P}(\mathrm{tCz}-\mathrm{co}-\mathrm{bTP})$; (c) $\mathrm{P}(\mathrm{tCz}-\mathrm{co}-\mathrm{CPDT}$ ); (d) $\mathrm{P}(\mathrm{tCz}-\mathrm{co}$-DTC); and (e) $\mathrm{P}(\mathrm{tCz}-\mathrm{co}$-CPDTK) electrodes in a solution.

Table 3. Electrochromic switching properties of the electrodes.

\begin{tabular}{|c|c|c|c|c|c|c|c|c|c|}
\hline Electrodes & $\lambda(\mathrm{nm})$ & $T_{\mathrm{ox}}$ & $T_{\text {red }}$ & $\Delta T$ & $\triangle \mathrm{OD}$ & $Q_{\mathrm{d}}\left(\mathrm{mC} \mathrm{cm}^{-2}\right)$ & $\eta\left(\mathrm{cm}^{2} \mathrm{C}^{-1}\right)$ & $\tau_{\mathrm{c}}(\mathrm{s})$ & $\tau_{\mathrm{b}}(\mathrm{s})$ \\
\hline $\mathrm{PtCz}$ & 760 & 33.0 & 63.5 & 30.5 & 0.284 & 6.660 & 42.6 & 6.0 & 5.0 \\
\hline $\mathrm{P}(\mathrm{tCz}-c o-b T P)$ & 967 & 9.5 & 52.5 & 43.0 & 0.742 & 10.986 & 67.6 & 6.5 & 5.0 \\
\hline $\mathrm{P}(\mathrm{tCz}-\mathrm{co}-\mathrm{CPDT})$ & 864 & 13.5 & 42.2 & 28.7 & 0.494 & 6.453 & 76.7 & 6.5 & 5.5 \\
\hline $\mathrm{P}(\mathrm{tC} z-c o-\mathrm{DTC})$ & 870 & 10.0 & 53.6 & 43.6 & 0.729 & 9.310 & 78.3 & 6.5 & 4.5 \\
\hline $\mathrm{P}(\mathrm{tC} \mathrm{z}-c o-\mathrm{CPDTK})$ & 984 & 19.5 & 44.0 & 24.5 & 0.353 & 5.653 & 62.5 & 5.5 & 3.5 \\
\hline
\end{tabular}


As shown in Table 4, $\mathrm{P}(\mathrm{tCz}-\mathrm{co}$-DTC) film showed higher transmittance change than those reported for poly(ethyl-4-(3,6-di(thiophen-2-yl)-9H-carbazole-9-yl)-benzoate) (PETCB) film at $1100 \mathrm{~nm}$ [15], poly(9H-carbazol-9-ylpyrene) (PMCzP) film at $460 \mathrm{~nm}$ [30], and poly(1,3-bis(carbazol-9-yl)benzene) $(\mathrm{PBCz})$ film at $1050 \mathrm{~nm}$ [31]. However, $\mathrm{P}(\mathrm{tCz}-\mathrm{co}-\mathrm{DTC})$ film showed a lower transmittance change than those reported for $\mathrm{P}\left(\mathrm{NO}_{2}-3 \mathrm{Cz}\right)$ film at $710 \mathrm{~nm}$ [14]. On the other hand, $\mathrm{P}(\mathrm{tCz}-\mathrm{co}-\mathrm{DTC})$ film revealed higher $\eta$ than that reported for $\mathrm{P}\left(\mathrm{NO}_{2}-3 \mathrm{Cz}\right)$ [14], whereas $\mathrm{P}(\mathrm{tCz}-\mathrm{co}-\mathrm{DTC})$ film presented lower $\eta$ than that reported for $\mathrm{PBCz}$ [31].

Table 4. Transmittance changes and colouration efficiencies of carbazole-based polymer films.

\begin{tabular}{cccc}
\hline Polymer Films & $\boldsymbol{\Delta} \boldsymbol{T}_{\max }(\boldsymbol{\%})$ & $\boldsymbol{\eta}\left(\mathbf{c m}^{\mathbf{2}} \mathbf{C}^{-\mathbf{1}}\right)$ & Ref. \\
\hline PETCB & $36(1100 \mathrm{~nm})$ & - & {$[15]$} \\
PMCzP & $29(460 \mathrm{~nm})$ & - & {$[30]$} \\
PBCz & $18.6(1050 \mathrm{~nm})$ & 180.3 & {$[31]$} \\
P(NO $-3 C z)$ & $52(710 \mathrm{~nm})$ & 35 & {$[14]$} \\
P(tCz-co-DTC $)$ & $43.6(870 \mathrm{~nm})$ & 78.3 & This work \\
\hline
\end{tabular}

\subsection{Spectroelectrochemistry of ECDs}

Figure 7 shows the UV-Vis spectra of dual-type $\mathrm{PtCz} / \mathrm{PProDOT}-\mathrm{Me}_{2}, \quad \mathrm{P}(\mathrm{tCz}-\mathrm{co}-$ $\mathrm{bTP}) /$ PProDOT-Me $\mathrm{M}_{2}$ and $\mathrm{P}(\mathrm{tCz}-\mathrm{co}-\mathrm{DTC}) /$ PProDOT-Me $\mathrm{M}_{2}$ ECDs at various applied potentials. At $0.0 \mathrm{~V}, \mathrm{PtCz}, \mathrm{P}(\mathrm{tCz}-\mathrm{co}-\mathrm{bTP})$, and $\mathrm{P}(\mathrm{tCz}-\mathrm{co}-\mathrm{DTC})$ films showed a bleached color in their neutral state and PProDOT-Me 2 was transparent in its oxidized state.
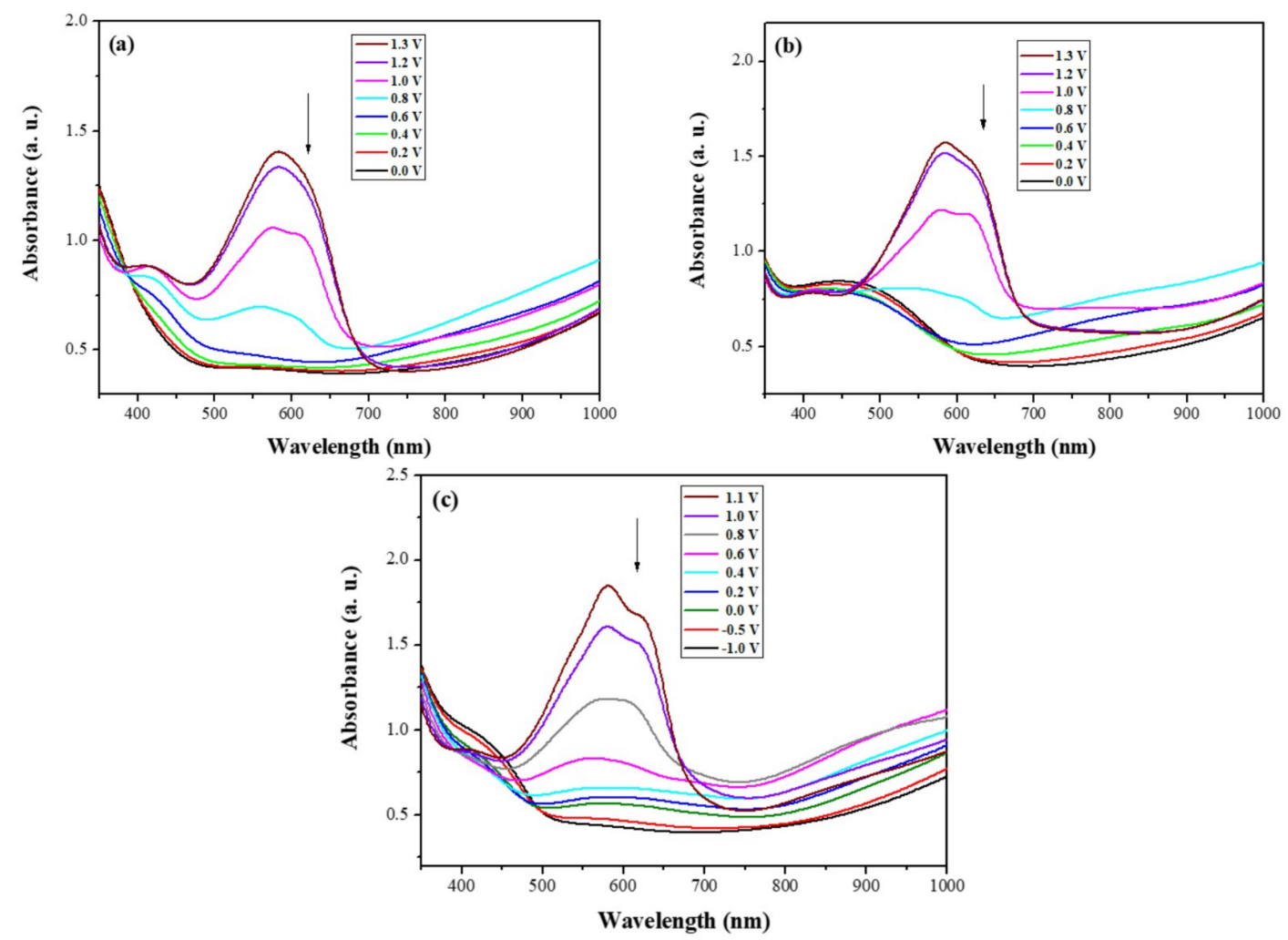

Figure 7. UV-Visible spectra of (a) PtCz/PProDOT-Me 2 ; (b) P(tCz-co-bTP)/PProDOT-Me ${ }_{2}$; and (c) $\mathrm{P}(\mathrm{tCZ}-\mathrm{co}$-DTC)/PProDOT-Me 2 ECDs.

Accordingly, $\quad \mathrm{PtCz} /$ PProDOT-Me $2, \quad \mathrm{P}(\mathrm{tCz}-\mathrm{co}-\mathrm{bTP}) /$ PProDOT-Me $\mathrm{M}_{2}, \quad$ and $\mathrm{P}(\mathrm{tCz}-\mathrm{co}-$ DTC)/PProDOT-Me $\mathrm{M}_{2}$ ECDs revealed a bleached color at $0.0 \mathrm{~V}$. Upon increasing the applied voltage from 0 to $1.3 \mathrm{~V}$ gradually, the absorption bands at 583-628 $\mathrm{nm}$ were emerged due to the 
absorption of PtCz, $\mathrm{P}(\mathrm{tCz}-\mathrm{co}-\mathrm{bTP})$, and $\mathrm{P}(\mathrm{tCz}-\mathrm{co}-\mathrm{DTC})$ films in their oxidized state and PProDOT-Me $\mathrm{M}_{2}$ film in its neutral state. The colors of $\mathrm{PtCz} / \mathrm{PProDOT}-\mathrm{Me}_{2}, \mathrm{P}(\mathrm{tCz}-\mathrm{co}-\mathrm{bTP}) /$ PProDOT-Me ${ }_{2}$, and $\mathrm{P}(\mathrm{tCz}-\mathrm{co}-\mathrm{DTC}) / \mathrm{PProDOT}-\mathrm{Me}_{2}$ ECDs were dark blue at $1.3 \mathrm{~V}$. Table 5 showed the photographs and colorimetric values of $\mathrm{P}(\mathrm{tCz}-\mathrm{co}-\mathrm{bTP}) / \mathrm{PProDOT}-\mathrm{Me}_{2}$ and $\mathrm{P}(\mathrm{tCz}-\mathrm{co}-\mathrm{DTC}) / \mathrm{PProDOT}-\mathrm{Me}_{2}$ ECDs at various potentials. $\mathrm{P}(\mathrm{tCz}-\mathrm{co}-\mathrm{bTP}) / \mathrm{PProDOT}-\mathrm{Me}_{2} \mathrm{ECD}$ revealed light tan, light brown, purple, blue, and dark blue at $0.0,0.4,0.6,0.8$, and $1.3 \mathrm{~V}$, respectively, whereas $\mathrm{P}(\mathrm{tCz}-\mathrm{co}-\mathrm{DTC}) / \mathrm{PProDOT}-\mathrm{Me}_{2} \mathrm{ECD}$ displayed light beige, grey, light grey, blue, and dark blue at $-1.0,0.0,0.4,0.6$, and $1.1 \mathrm{~V}$, respectively.

\subsection{Electrochemical Switching of ECDs}

The double-potential-step chronoamperometry experiments of $\mathrm{PtCz} / \mathrm{PProDOT}_{\mathrm{Me}}$, $\mathrm{P}(\mathrm{tCz}-\mathrm{co}-\mathrm{bTP}) / \mathrm{PProDOT}-\mathrm{Me}_{2}$, and $\mathrm{P}(\mathrm{tCz}-\mathrm{co}-\mathrm{DTC}) / \mathrm{PProDOT}-\mathrm{Me}_{2}$ ECDs were implemented by stepping potentials between bleached and colored states, the time interval being $10 \mathrm{~s}$. Figure 8 showed the transmittance-time profiles of $\mathrm{PtCz} / \mathrm{PProDOT}-\mathrm{Me}_{2}, \mathrm{P}(\mathrm{tCz}-\mathrm{co}-\mathrm{bTP}) / \mathrm{PProDOT}-\mathrm{Me}_{2}$, and $\mathrm{P}(\mathrm{tCz}-\mathrm{co}-\mathrm{DTC}) / \mathrm{PProDOT}-\mathrm{Me}_{2}$ ECDs, and the $\Delta T, \eta$, and the switching time of $\mathrm{PtC} z / \mathrm{PProDOT}-\mathrm{Me}_{2}$,

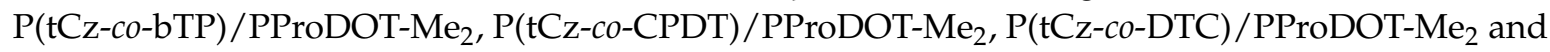
$\mathrm{P}(\mathrm{tCz}-\mathrm{co}-\mathrm{CPDTK}) / \mathrm{PProDOT}-\mathrm{Me}_{2}$ ECDs were presented in Table 6. The $\Delta T$ of PtCz/PProDOT-Me ${ }_{2}$,

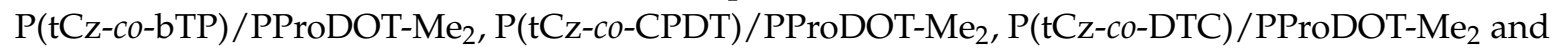
$\mathrm{P}(\mathrm{tCz}-\mathrm{co}-\mathrm{CPDTK}) / \mathrm{PProDOT}-\mathrm{Me}_{2}$ ECDs were estimated to be $30.9 \%$ at $583 \mathrm{~nm}, 32.0 \%$ at $628 \mathrm{~nm}$, $19.7 \%$ at $582 \mathrm{~nm}, 45.9 \%$ at $624 \mathrm{~nm}$, and $29.5 \%$ at $582 \mathrm{~nm}$, respectively. P(tCz-co-DTC)/PProDOT-Me ECD showed the highest $\Delta T$, and $\mathrm{P}(\mathrm{tCz}-\mathrm{co}-\mathrm{bTP}) / \mathrm{PProDOT}-\mathrm{Me}_{2} \mathrm{ECD}$ showed higher $\Delta T$ than that of $\mathrm{PtCz} / \mathrm{PProDOT}-\mathrm{Me}_{2} \mathrm{ECD}$, indicating that the incorporation of copolymers $(\mathrm{P}(\mathrm{tCz}-\mathrm{co}-\mathrm{bTP})$ and $\mathrm{P}(\mathrm{tCz}-\mathrm{co}$-DTC $))$ as the anodically coloring layers leading to a higher $\Delta T$ than that of the homopolymer (PtCz). In similar situation, $\mathrm{P}(\mathrm{tCz}-\mathrm{co}-\mathrm{bTP}) / \mathrm{PProDOT}-\mathrm{Me}_{2}$ and $\mathrm{P}(\mathrm{tCz}-\mathrm{co}-\mathrm{DTC}) / \mathrm{PProDOT}-\mathrm{Me}_{2}$ ECDs showed higher $\triangle \mathrm{OD}$ than that of PtCz/PProDOT-Me ${ }_{2}$ ECD. On the other side, the $\eta$ of dual-type PtCz/PProDOT-Me ${ }_{2}, \mathrm{P}(\mathrm{tCz}-\mathrm{co}-\mathrm{bTP}) /$ PProDOT-Me 2 , P(tCz-co-CPDT)/PProDOT-Me ${ }_{2}$, $\mathrm{P}(\mathrm{tCz}-\mathrm{co}-\mathrm{DTC}) /$ PProDOT-Me $\mathrm{M}_{2}$ and P(tCz-co-CPDTK)/PProDOT-Me $\mathrm{e}_{2}$ ECDs were $437.4 \mathrm{~cm}^{2} \mathrm{C}^{-1}$ at 583 $\mathrm{nm}, 387.0 \mathrm{~cm}^{2} \mathrm{C}^{-1}$ at $628 \mathrm{~nm}, 419.7 \mathrm{~cm}^{2} \mathrm{C}^{-1}$ at $582 \mathrm{~nm}, 400.5 \mathrm{~cm}^{2} \mathrm{C}^{-1}$ at $624 \mathrm{~nm}$, and $513.0 \mathrm{~cm}^{2} \mathrm{C}^{-1}$ at $582 \mathrm{~nm}$, respectively. $\mathrm{P}\left(\mathrm{tCz}-\mathrm{co}\right.$-CPDTK)/PProDOT-Me $\mathrm{M}_{2} \mathrm{ECD}$ showed the highest $\eta$ among these ECDs. The $\tau_{\mathrm{c}}$ and $\tau_{\mathrm{b}}$ estimated for dual-type PtCz/PProDOT-Me ${ }_{2}, \mathrm{P}(\mathrm{tCz}-\mathrm{co}-\mathrm{bTP}) /$ PProDOT-Me $\mathrm{M}_{2}$ $\mathrm{P}(\mathrm{tCz}-\mathrm{co}-\mathrm{CPDT}) / \mathrm{PProDOT}-\mathrm{Me}_{2}, \mathrm{P}(\mathrm{tCz}-\mathrm{co}-\mathrm{DTC}) / \mathrm{PProDOT}-\mathrm{Me}_{2}$, and $\mathrm{P}(\mathrm{tCz}-\mathrm{co}-\mathrm{CPDTK}) / \mathrm{PProDOT}-\mathrm{Me}_{2}$ ECDs are also shown in Table 6. The $\tau_{\mathrm{s}}$ of dual-type ECDs were shorter than those of their corresponding anodic polymer films, indicating that the dual-type ECDs revealed a short distance between the two electrodes. $\mathrm{P}(\mathrm{tCz}-\mathrm{co}-\mathrm{bTP}) /$ PProDOT-Me ${ }_{2}$ ECD showed the shortest $\tau$ among these ECDs.

Table 5. Photographs and colorimetric values of ECDs at different potentials.

\begin{tabular}{|c|c|c|c|c|c|c|c|c|}
\hline ECDs & Potentials(V) & Photographs & $\mathrm{L}^{*}$ & $a^{*}$ & $\mathbf{b}^{*}$ & $x$ & $y$ & Diagrams \\
\hline \multirow{5}{*}{$\begin{array}{l}\mathrm{P}(\mathrm{tC} z-c o-b T P) / \\
\text { PProDOT-Me } 2\end{array}$} & 0.0 & & 59.28 & 17.14 & 23.93 & 0.5180 & 0.4040 & \\
\hline & 0.4 & & 60.06 & 11.55 & 21.45 & 0.5022 & 0.4120 & \\
\hline & 0.6 & & 58.60 & 8.09 & 18.02 & 0.4912 & 0.4150 & \\
\hline & 0.8 & & 48.18 & 6.06 & 1.66 & 0.4666 & 0.3980 & \\
\hline & 1.3 & & 25.92 & 0.87 & -35.37 & 0.3387 & 0.3039 & \\
\hline \multirow{5}{*}{$\begin{array}{l}\text { P(tCz-co-DTC }) / \\
\text { PProDOT-Me } 2\end{array}$} & -1.0 & & 66.76 & 1.24 & 29.12 & 0.4848 & 0.4368 & \\
\hline & 0.0 & & 59.60 & -1.10 & 10.31 & 0.4597 & 0.4228 & \\
\hline & 0.4 & & 54.42 & -0.90 & 2.01 & 0.4485 & 0.4120 & \\
\hline & 0.6 & & 46.72 & 2.84 & -6.41 & 0.4434 & 0.3912 & \\
\hline & 1.1 & & 20.49 & 5.63 & -38.24 & 0.3299 & 0.2703 & \\
\hline
\end{tabular}



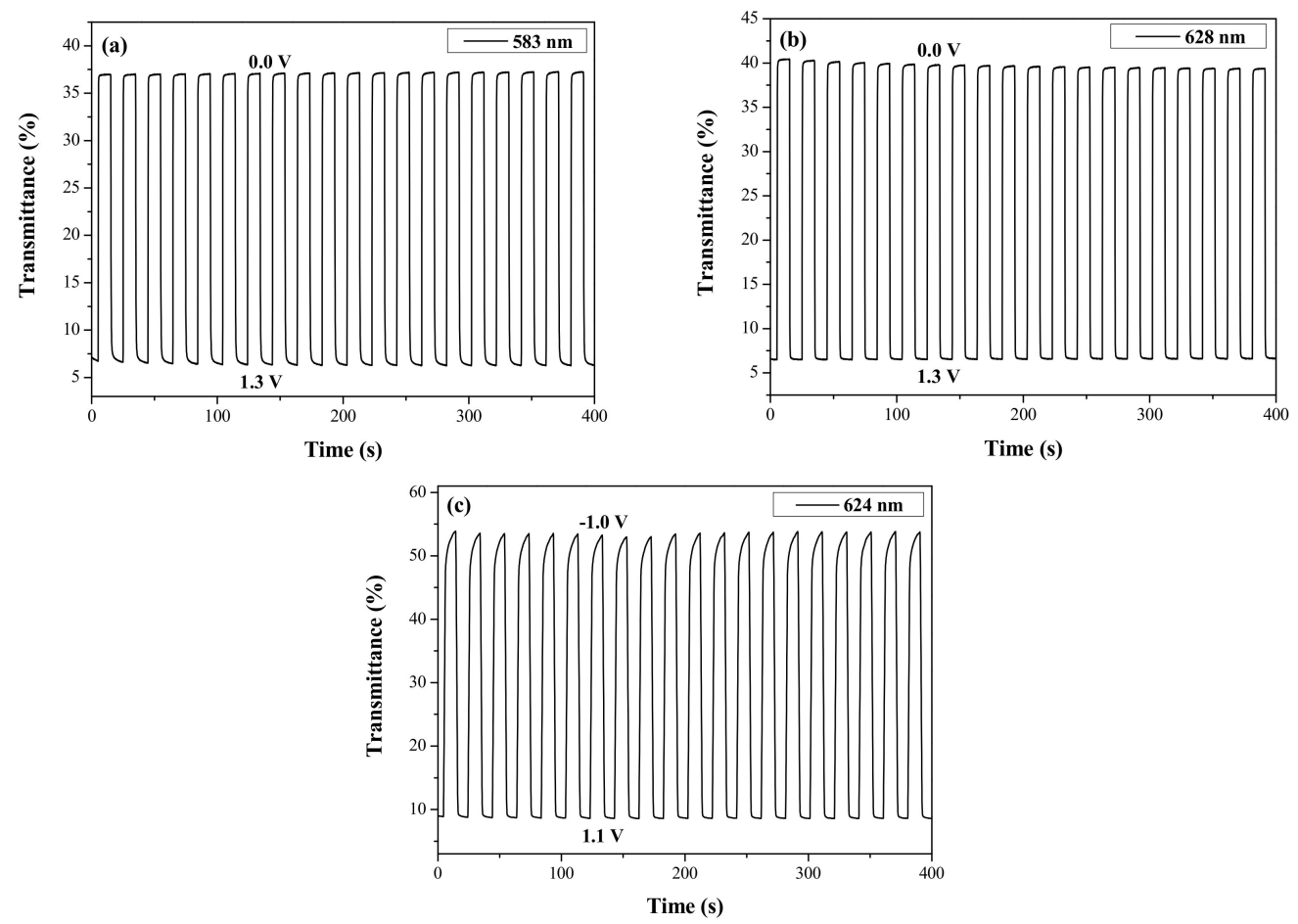

Figure 8. Transmittance-time profiles of (a) PtCz/PProDOT-Me 2 ; (b) P(tCz-co-bTP)/PProDOT-Me ; and (c) $\mathrm{P}(\mathrm{tCz}-\mathrm{co}-\mathrm{DTC}) / \mathrm{PProDOT}-\mathrm{Me}_{2}$ ECDs carried out by stepping potentials between bleached and colored states with a residence time of $10 \mathrm{~s}$.

Table 6. Electrochromic properties of the devices.

\begin{tabular}{|c|c|c|c|c|c|c|c|c|c|}
\hline Devices & $\lambda(\mathrm{nm})$ & $T_{\text {ox }}$ & $T_{\text {red }}$ & $\Delta T$ & $\Delta \mathrm{OD}$ & $Q_{\mathrm{d}}\left(\mathrm{mC} \mathrm{cm}^{-2}\right)$ & $\eta\left(\mathrm{cm}^{2} \mathrm{C}^{-1}\right)$ & $\tau_{\mathrm{c}}(\mathrm{s})$ & $\tau_{\mathrm{b}}(\mathrm{s})$ \\
\hline PtCz/PProDOT-Me 2 & 583 & 6.6 & 37.5 & 30.9 & 0.754 & 1.724 & 437.4 & 0.9 & 0.4 \\
\hline $\begin{array}{l}\mathrm{P}(\mathrm{tCz}-c o-b T P) \\
/ \text { PProDOT-Me }\end{array}$ & 628 & 6.7 & 38.7 & 32.0 & 0.761 & 1.968 & 387.0 & 0.4 & 0.2 \\
\hline $\begin{array}{l}\mathrm{P}(\mathrm{tCz}-c o-\mathrm{CPDT}) \\
/ \text { PProDOT-Me }\end{array}$ & 582 & 7.4 & 27.1 & 19.7 & 0.563 & 1.343 & 419.7 & 0.3 & 0.5 \\
\hline $\begin{array}{l}\text { P(tCz-co-DTC) } \\
/ \text { PProDOT-Me }\end{array}$ & 624 & 8.6 & 54.5 & 45.9 & 0.801 & 2.001 & 400.5 & 1.2 & 1.6 \\
\hline $\begin{array}{l}\mathrm{P}(\mathrm{tCz}-c o-\mathrm{CPDTK}) \\
/ \text { PProDOT-Me }\end{array}$ & 582 & 7.6 & 37.1 & 29.5 & 0.688 & 1.342 & 513.0 & 0.6 & 0.2 \\
\hline
\end{tabular}

Table 7 shows the comparisons of $\Delta T_{\max }$ and $\eta_{\max }$ with reported ECDs. $\mathrm{P}\left(\mathrm{tCz}-\mathrm{co}\right.$-DTC)/PProDOT- $\mathrm{Me}_{2}$ ECD shows higher $\Delta T_{\max }$ than those reported for $\mathrm{P}(\mathrm{dcbp}-\mathrm{co}$-cpdt)/PEDOT [32], P(dcbp)/PEDOT [33], P(dcbp-co-bt)/PEDOT [34], P(bmco)/PEDOT [35], $\mathrm{P}(\mathrm{BCz}-\mathrm{co}$-ProD)/tri-l poly(3,4-ethylenedioxythiophene)-poly(styrene sulfonic acid) (PEDOT-PSS) [31], and P(BCz-co-In)/PProDOT-Et 2 ECDs [36].

Table 7. $\Delta T$ and $\eta$ of ECDs.

\begin{tabular}{|c|c|c|c|}
\hline ECD Configurations & $\Delta T_{\max }(\%)$ & $\eta_{\max }\left(\mathrm{cm}^{2} \mathrm{C}^{-1}\right)$ & Ref. \\
\hline $\mathrm{P}(\mathrm{dcbp}-c o-\mathrm{cpdt}) / \mathrm{PEDOT}$ & $39.8(628 \mathrm{~nm})$ & $319.98(628 \mathrm{~nm})$ & [32] \\
\hline $\mathrm{P}(\mathrm{dcbp}) / \mathrm{PEDOT}$ & $19(550 \mathrm{~nm})$ & - & [33] \\
\hline $\mathrm{P}(\mathrm{dcbp}-\mathrm{co}-\mathrm{bt}) / \mathrm{PEDOT}$ & $28.6(700 \mathrm{~nm})$ & $234(700 \mathrm{~nm})$ & [34] \\
\hline $\mathrm{P}(\mathrm{bmco}) / \mathrm{PEDOT}$ & $35(620 \mathrm{~nm})$ & - & [35] \\
\hline P(BCz-co-ProD)/tri-1 PEDOT-PSS & $41(642 \mathrm{~nm})$ & $417(642 \mathrm{~nm})$ & [31] \\
\hline $\mathrm{P}\left(\mathrm{BC}\right.$-co-In) $/ \mathrm{PProDOT}^{-\mathrm{Et}_{2}}$ & $42.0(587 \mathrm{~nm})$ & $634(587 \mathrm{~nm})$ & [36] \\
\hline $\mathrm{P}(\mathrm{tCz}-c o-\mathrm{DTC}) /$ PProDOT-Me 2 & $45.9(624 \mathrm{~nm})$ & $401(624 \mathrm{~nm})$ & This work \\
\hline
\end{tabular}


Moreover, the comparison of $\eta_{\max }$ with reported ECDs revealed that $\mathrm{P}(\mathrm{tCz}-\mathrm{co}-\mathrm{DTC}) / \mathrm{PProDOT}-$ $\mathrm{Me}_{2}$ ECD showed higher $\eta_{\max }$ than those reported for $\mathrm{P}(\mathrm{dcbp}$-co-cpdt)/PEDOT [32] and $\mathrm{P}(\mathrm{dcbp}-\mathrm{co}-\mathrm{bt}) / \mathrm{PEDOT}$ ECDs [34]. However, $\mathrm{P}(\mathrm{tCz}-\mathrm{co}-\mathrm{DTC}) / \mathrm{PProDOT}-\mathrm{Me}_{2}$ ECD showed lower $\eta_{\max }$ than those reported for P(BCz-co-ProD)/tri-l PEDOT-PSS [31] and P(BCz-co-In)/PProDOT-Et 2 ECDs [36].

\subsection{Open Circuit Memory}

The open circuit memory of ECDs is a crucial property due to it is related to the energy-saving of ECDs $[37,38]$. The open circuit stability of PtCz/PProDOT-Me $2, \mathrm{P}(\mathrm{tCz}-\mathrm{co}-\mathrm{bTP}) / \mathrm{PProDOT}-\mathrm{Me}_{2}$, and $\mathrm{P}(\mathrm{tCz}-\mathrm{co}-\mathrm{DTC}) / \mathrm{PProDOT}-\mathrm{Me}_{2}$ ECDs as shown in Figure $9 \mathrm{a}-\mathrm{c}$ was detected at 583, 628, and $624 \mathrm{~nm}$, respectively, by applying potentials at bleached and colored states for $1 \mathrm{~s}$ at each $100 \mathrm{~s}$ time interval. PtCz/PProDOT-Me $2, \mathrm{P}(\mathrm{tCz}-\mathrm{co}-\mathrm{bTP}) /$ PProDOT-Me ${ }_{2}$, and P(tCz-co-DTC)/PProDOT-Me 2 ECDs were nearly no transmittance change at bleached state. However, the open circuit stability of PtCz/PProDOT-Me 2 , P(tCz-co-bTP)/PProDOT-Me $e_{2}$ and P(tCz-co-DTC)/PProDOT-Me $\mathrm{M}_{2}$ ECDs at colored state were less stable than that at bleached state. The transmittance changes of these ECDs were less than $5 \%$ at the colored state, indicating that $\mathrm{PtCz} / \mathrm{PProDOT}-\mathrm{Me}_{2}, \mathrm{P}(\mathrm{tCz}-\mathrm{co}-\mathrm{bTP}) / \mathrm{PProDOT}-\mathrm{Me}_{2}$, and $\mathrm{P}(\mathrm{tCZ}-\mathrm{co}-\mathrm{DTC}) / \mathrm{PProDOT}-\mathrm{Me}_{2}$ ECDs would not need a refreshing current for retaining their colors in bleached and colored states.
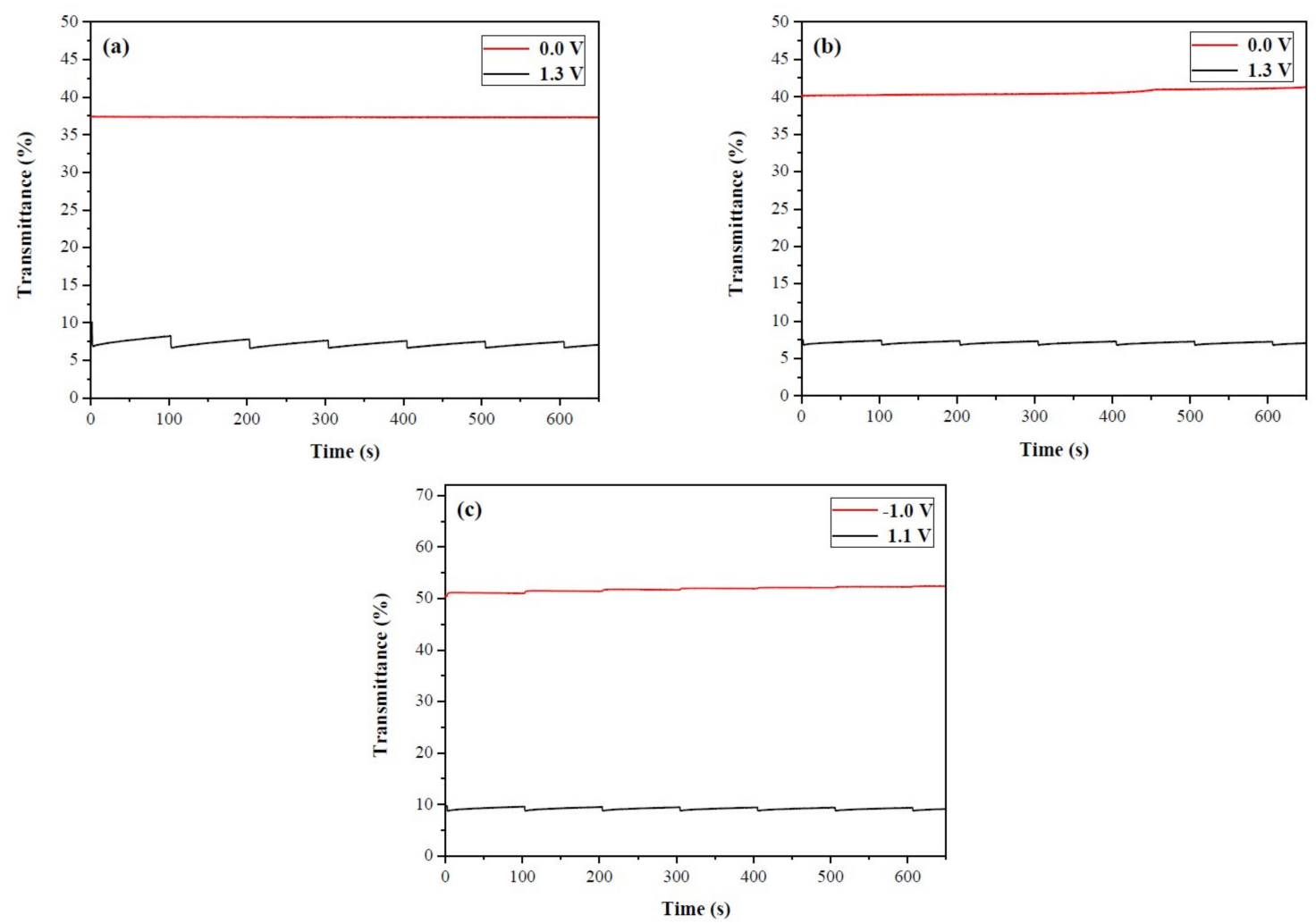

Figure 9. Open circuit stability of (a) PtCz/PProDOT-Me 2 ; (b) $\mathrm{P}(\mathrm{tCz}-\mathrm{co}-\mathrm{bTP}) / \mathrm{PProDOT}-\mathrm{Me}_{2}$; and (c) $\mathrm{P}(\mathrm{tCz}-\mathrm{co}-\mathrm{DTC}) / \mathrm{PProDOT}-\mathrm{Me}_{2}$ ECDs.

\subsection{Stability}

The redox stabilities of $\mathrm{PtCz} / \mathrm{PProDOT}-\mathrm{Me}_{2}, \mathrm{P}(\mathrm{tCz}-\mathrm{co}-\mathrm{bTP}) /$ PProDOT-Me $\mathrm{M}_{2}$ and $\mathrm{P}(\mathrm{tCz}-\mathrm{co}-$ DTC)/PProDOT-Me $2_{2}$ ECDs were monitored by CV at 1st, 500th and 1000th cycles [39,40], the scan rate was $500 \mathrm{mV} \mathrm{s}^{-1}$. As shown in Figure 10, 96.0\%, 93.6\%, and $96.7 \%$ of their electroactivities were maintained after the 500th cycle for $\mathrm{PtCz} / \mathrm{PProDOT}-\mathrm{Me}_{2}$, $\mathrm{P}(\mathrm{tCz}-\mathrm{co}-\mathrm{bTP}) / \mathrm{PProDOT}-\mathrm{Me}_{2}$, and P(tCz-co-DTC)/PProDOT-Me 2 ECDs, respectively, and 95.5\%, 
$90.3 \%$, and $96.0 \%$ of their electroactivities were maintained after the 1000th cycle for $\mathrm{PtC}_{\mathrm{t}} / \mathrm{PProDOT}-\mathrm{Me}_{2}, \mathrm{P}(\mathrm{tCz}-\mathrm{co}-\mathrm{bTP}) /$ PProDOT-Me $\mathrm{M}_{2}$ and $\mathrm{P}(\mathrm{tCz}-\mathrm{co}-\mathrm{DTC}) / \mathrm{PProDOT}-\mathrm{Me}_{2}$ ECDs, respectively. Considering these results, ECDs employ $\mathrm{P}(\mathrm{tCz}-\mathrm{co}-\mathrm{bTP})$ and $\mathrm{P}(\mathrm{tCz}-\mathrm{co}-\mathrm{DTC})$ as anodic polymer films show potential for use in auto-dimming car mirror and motorcycle helmet-visors.
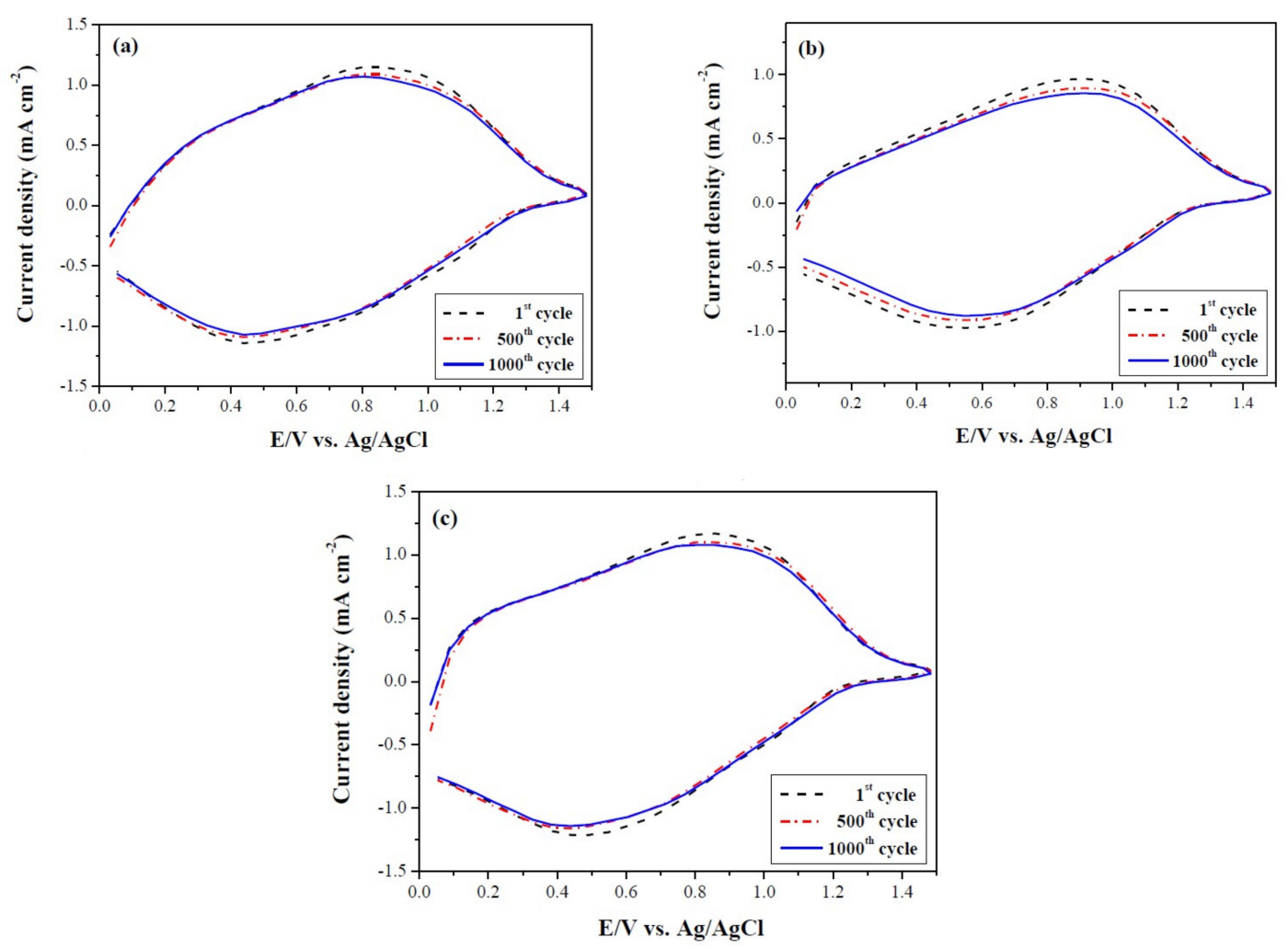

Figure 10. Cyclic voltammograms of (a) PtCz/PProDOT-Me $;$ (b) $\mathrm{P}(\mathrm{tCz}-\mathrm{co}-\mathrm{bTP}) / \mathrm{PProDOT}-\mathrm{Me}_{2}$; and (c) $\mathrm{P}(\mathrm{tCz}-\mathrm{co}-\mathrm{DTC}) / \mathrm{PProDOT}-\mathrm{Me}_{2}$ ECDs at the first, 500th, and 1000th cycles.

\section{Conclusions}

Copolymers (P(tCz-co-bTP), $\mathrm{P}(\mathrm{tCz}-\mathrm{co}-\mathrm{CPDT}), \mathrm{P}(\mathrm{tCz}-\mathrm{co}-\mathrm{DTC})$, and $\mathrm{P}(\mathrm{tCz}-\mathrm{co}-\mathrm{CPDTK}))$ were copolymerized electrochemically. Spectroelectrochemical investigations showed that $\mathrm{P}(\mathrm{tCz}-\mathrm{co}-\mathrm{CPDT})$ film revealed three different colors (light grey, green, and dark blue) at various voltages, whereas the color variations of $\mathrm{P}(\mathrm{tCz}-\mathrm{co}-\mathrm{DTC})$ film were light yellow at $0.0 \mathrm{~V}$, yellow at $0.6 \mathrm{~V}$, blue at $0.8 \mathrm{~V}$, and black at 1.3 V. Five dual-type ECDs based on PtCz, P(tCz-co-bTP), P(tCz-co-CPDT), P(tCz-co-DTC), and $\mathrm{P}(\mathrm{tCz}-\mathrm{co}-\mathrm{CPDTK})$ films as anodic polymers and PProDOT-Me $\mathrm{e}_{2}$ as the cathodic polymer were constructed and their electrochromic properties were characterized. $\mathrm{P}(\mathrm{tCz}-\mathrm{co}-\mathrm{bTP}) / \mathrm{PProDOT}-\mathrm{Me}_{2}$ ECD showed high $\Delta T_{\max }(32 \%$ at $628 \mathrm{~nm})$ and fast switching time (less than $\left.0.4 \mathrm{~s}\right)$, whereas $\mathrm{P}\left(\mathrm{tCz}-\mathrm{co}\right.$-DTC)/PProDOT-Me $\mathrm{e}_{2} \mathrm{ECD}$ revealed high $\Delta T_{\max }(45.9 \%$ at $624 \mathrm{~nm})$, high open circuit stability, and high redox stability after 1000 cycles, which makes $\mathrm{P}(\mathrm{tCz}-\mathrm{co}-\mathrm{bTP})$ and $\mathrm{P}(\mathrm{tCz}-\mathrm{co}-\mathrm{DTC})$ promising anodic copolymer films for ECDs' applications.

Author Contributions: P.-Y.L. and C.-W.K. implemented the experiments. T.-Y.W., C.-W.K., J.-C.C., and Y.-C.H. analyzed the electrochromic properties.

Conflicts of Interest: The authors declare no conflict of interest.

\section{References}

1. Mortimer, R.G. Electrochromic materials. Chem. Soc. Rev. 1997, 26, 147-156. [CrossRef]

2. Kline, W.M.; Lorenzini, R.G.; Sotzing, G.A. A review of organic electrochromic fabric devices. Color Technol. 2014, 130, 73-80. [CrossRef] 
3. Beaujuge, P.M.; Reynolds, J.R. Color control in $\pi$-conjugated organic polymers for use in electrochromic devices. Chem. Rev. 2010, 110, 268-320. [CrossRef] [PubMed]

4. Ming, S.; Zhang, S.; Liu, H.; Zhao, Y.; Mo, D.; Xu, J. Methacrylate modified polythiophene: Electrochemistry and electrochromics. Int. J. Electrochem. Sci. 2015, 10, 6598-6609.

5. Lin, K.; Zhang, S.; Liu, H.; Zhao, Y.; Wang, Z.; Xu, J. Effects on the electrochemical and electrochromic properties of 3 linked polythiophene derivative by the introduction of polyacrylate. Int. J. Electrochem. Sci. 2015, 10, 7720-7731.

6. Hsiao, S.H.; Hsueh, J.C. Electrochemical synthesis and electrochromic properties of new conjugated polycarbazoles from di(carbazol-9-yl)-substituted triphenylamine and $N$-phenylcarbazole derivatives. J. Electroanal. Chem. 2015, 758, 100-110. [CrossRef]

7. Soyleyici, S.; Karakus, M.; Ak, M. Transparent-blue colored dual type electrochromic device: Switchable glass application of conducting organic-inorganic hybrid carbazole polymer. J. Electrochem. Soc. 2016, 163, H679-H683. [CrossRef]

8. Wu, T.Y.; Chung, H.H. Applications of tris(4-(thiophen-2-yl)phenyl)amine- and dithienylpyrrole-based conjugated copolymers in high-contrast electrochromic devices. Polymers 2016, 8, 206-221. [CrossRef]

9. Hsiao, S.H.; Lu, H.Y. Electrosynthesis of aromatic poly(amide-amine) films from triphenylamine-based electroactive compounds for electrochromic applications. Polymers 2017, 9, 708. [CrossRef]

10. Kuo, C.W.; Chen, B.K.; Li, W.B.; Tseng, L.Y.; Wu, T.Y.; Tseng, C.G.; Chen, H.R.; Huang, Y.C. Effects of supporting electrolytes on spectroelectrochemical and electrochromic properties of polyaniline-poly(styrene sulfonic acid) and poly(ethylenedioxythiophene)-poly(styrene sulfonic acid)-based electrochromic device. J. Chin. Chem. Soc. 2014, 61, 563-570. [CrossRef]

11. Kuo, C.W.; Wu, T.Y.; Fan, S.C. Applications of poly(indole-6-carboxylic acid-co-2,2'-bithiophene) films in high-contrast electrochromic devices. Coatings 2018, 8, 102. [CrossRef]

12. Nie, G.M.; Zhou, L.J.; Yang, H.J. Electrosynthesis of a new polyindole derivative obtained from 5-formylindole and its electrochromic properties. J. Mater. Chem. 2011, 21, 13873-13880. [CrossRef]

13. Yu, W.; Chen, J.; Fu, Y.; Xu, J.; Nie, G. Electrochromic property of a copolymer based on 5-cyanoindole and 3,4-ethylenedioxythiophene and its application in electrochromic devices. J. Electroanal. Chem. 2013, 700, 17-23. [CrossRef]

14. Hsiao, S.H.; Lin, S.W. Electrochemical synthesis of electrochromic polycarbazole films from $\mathrm{N}$-phenyl-3,6-bis(N-carbazolyl)carbazoles. Polym. Chem. 2016, 7, 198-211. [CrossRef]

15. Hu, B.; Lv, X.; Sun, J.; Bian, G.; Ouyang, M.; Fu, Z.; Wang, P.; Zhang, C. Effects on the electrochemical and electrochromic properties of 3,6 linked polycarbazole derivative by the introduction of different acceptor groups and copolymerization. Org. Electron. 2013, 14, 1521-1530. [CrossRef]

16. Soganci, T.; Soyleyici, H.C.; Ak, M.; Cetisli, H. An amide substituted dithienylpyrrole based copolymer: Its electrochromic properties. J. Electrochem. Soc. 2016, 163, H59-H66. [CrossRef]

17. Zhang, Y.; Liu, X.; Wang, M.; Liu, X.; Zhao, J. Low band gap donor-acceptor type polymers containing 2,3-bis(4-(decyloxy)phenyl)pyrido[4,3-b]pyrazine as acceptor and different thiophene derivatives as donors. Polymers 2016, 8, 377-395. [CrossRef]

18. Weng, X.; Wu, S.; Liu, Y.; Wan, Z.; Jia, C.; Xie, J.; Deng, L. Novel electrochromic and infrared emissivity modulation films based on poly(carbazoyltriphenylamine) and poly(carbazoyltriphenylaminethiophene). Org. Electron. 2017, 51, 190-199. [CrossRef]

19. Yiğit, D.; Hacioglub, S.O.; Güllüa, M.; Toppare, L. Synthesis and spectroelectrochemical characterization of multi-colored novel poly(3,6-dithienylcarbazole) derivatives containing azobenzene and coumarin chromophore units. Electrochim. Acta 2016, 196, 140-152. [CrossRef]

20. Kuo, C.W.; Hsieh, T.H.; Hsieh, C.K.; Liao, J.W.; Wu, T.Y. Electrosynthesis and characterization of four electrochromic polymers based on carbazole and indole-6-carboxylic acid and their applications in high-contrast electrochromic devices. J. Electrochem. Soc. 2014, 161, D782-D790. [CrossRef]

21. Karon, K.; Lapkowski, M.; Dabuliene, A.; Tomkeviciene, A.; Kostiv, N.; Grazulevicius, J.V. Spectroelectrochemical characterization of conducting polymers from star-shaped carbazole-triphenylamine compounds. Electrochim. Acta 2015, 154, 119-127. [CrossRef] 
22. Su, Y.S.; Wu, T.Y. Three carbazole-based polymers as potential anodically coloring materials for high-contrast electrochromic devices. Polymers 2017, 9, 284. [CrossRef]

23. Welsh, D.M.; Kumar, A.; Meijer, E.W.; Reynolds, J.R. Enhanced contrast ratio and rapid switching in electrochromics based on poly(3,4-propylenedioxythiophene) derivatives. Adv. Mater. 1999, 11, 1379-1382. [CrossRef]

24. Kham, K.; Sadki, S.; Chevrot, C. Oxidative electropolymerizations of carbazole derivatives in the presence of bithiophene. Synth. Met. 2004, 145, 135-140. [CrossRef]

25. Feng, G.Q.; Wang, Z.; Gao, Q.X.; Chen, S.; Xu, X.L. Electrosyntheses and characterizations of a new multielectrochromic copolymer of 1-(3-methylthiophen-2-yl)pyrene and 3,4-ethylenedioxythiophene. Int. J. Electrochem. Sci. 2014, 9, 5820-5836.

26. Soganci, T.; Soyleyici, S.; Soyleyici, H.C.; Ak, M. High contrast electrochromic polymer and copolymer materials based on amide-substituted poly(dithienyl pyrrole). J. Electrochem. Soc. 2017, 164, H11-H20. [CrossRef]

27. Hacioglu, S.O.; Yiğit, D.; Ermis, E.; Soylemez, S.; Güllü, M.; Toppare, L. Syntheses and electrochemical characterization of low oxidation potential nitrogen analogs of pedot as electrochromic materials. J. Electrochem. Soc. 2016, 163, E293-E299. [CrossRef]

28. Wu, T.Y.; Liao, J.W.; Chen, C.Y. Electrochemical synthesis, characterization and electrochromic properties of indan and 1,3-benzodioxole-based poly(2,5-dithienylpyrrole) derivatives. Electrochim. Acta 2014, 150, 245-262. [CrossRef]

29. Kuo, C.W.; Wu, B.W.; Chang, J.K.; Chang, J.C.; Lee, L.T.; Wu, T.Y.; Ho, T.H. Electrochromic devices based on poly(2,6-di(9H-carbazol-9-yl)pyridine)-type polymer films and PEDOT-PSS. Polymers 2018, 10, 604. [CrossRef]

30. Wang, B.; Zhao, J.; Xiao, J.; Cui, C.; Liu, R. Synthesis and electropolymerization of 9H-carbazol-9-ylpyrene and its electrochromic properties and electrochromic device application. Int. J. Electrochem. Sci. 2012, 7, 2781-2795.

31. Kuo, C.W.; Wu, T.L.; Lin, Y.C.; Chang, J.K.; Chen, H.R.; Wu, T.Y. Copolymers based on 1,3-bis(carbazol-9yl)benzene and three 3,4-ethylenedioxythiophene derivatives as potential anodically coloring copolymers in high-contrast electrochromic devices. Polymers 2016, 8, 368. [CrossRef]

32. Chen, S.; Gao, Q.; Zhao, J.; Cui, C.; Yang, W.; Zhang, X. Electrosynthesis, characterizations and electrochromic properties of a novel copolymer of 4,4'-di( $N$-carbazoyl)biphenyl with $4 \mathrm{H}$-cyclopenta[2,1-b:3,4-b'] dithiophene. Int. J. Electrochem. Sci. 2012, 7, 5256-5272.

33. Koyuncu, S.; Gultekin, B.; Zafer, C.; Bilgili, H.; Can, M.; Demic, S.; Kaya, I.; Icli, S. Electrochemical and optical properties of biphenyl bridged-dicarbazole oligomer films: electropolymerization and electrochromism. Electrochim. Acta 2009, 54, 5694-5702. [CrossRef]

34. Wang, B.; Zhao, J.; Liu, R.; Liu, J.; He, Q. Electrosyntheses, characterizations and electrochromic properties of a copolymer based on 4,4'-di(N-carbazoyl)biphenyl and 2,2'-bithiophene. Sol. Energy Mater. Sol. Cells 2011, 95, 1867-1874. [CrossRef]

35. Udum, Y.A.; Hızlıateş, C.G.; Ergün, Y.; Toppare, L. Electrosynthesis and characterization of an electrochromic material containing biscarbazole-oxadiazole units and its application in an electrochromic device. Thin Solid Films 2015, 595, 61-67. [CrossRef]

36. Kuo, C.W.; Wu, T.Y.; Huang, M.W. Electrochromic characterizations of copolymers based on 4,4-bis( $N$-carbazolyl)-1,1-biphenyl and indole-6-carboxylic acid and their applications in electrochromic devices. J. Taiwan Inst. Chem. Eng. 2016, 6, 481-488. [CrossRef]

37. Wu, T.Y.; Li, J.L. Electrochemical synthesis, optical, electrochemical and electrochromic characterizations of indene and 1,2,5-thiadiazole-based poly(2,5-dithienylpyrrole) derivatives. RSC Adv. 2016, 6, 15988-15998. [CrossRef]

38. Kuo, C.W.; Lee, P.Y. Electrosynthesis of copolymers based on 1,3,5-tris( $N$-carbazolyl)benzene and 2,2'-bithiophene and their applications in electrochromic devices. Polymers 2017, 9, 518. [CrossRef] 
39. Guzel, M.; Karatas, E.; Ak, M. Synthesis and fluorescence properties of carbazole based asymmetric functionalized star shaped polymer. J. Electrochem. Soc. 2017, 164, H49-H55. [CrossRef]

40. Wu, T.Y.; Su, Y.S. Electrochemical synthesis and characterization of 1,4-benzodioxan-based electrochromic polymer and its application in electrochromic devices. J. Electrochem. Soc. 2015, 162, G103-G112. [CrossRef] 